\title{
VYTAUTO DIDŽIOJO AUKŠTOSIOS KARO MOKYKLOS VEIKLA (1931-1940 M.)
}

\author{
Doc. dr. Feliksas Žigaras
}

\begin{abstract}
Anotacija. 1921 m. balandžio 1 d. buvo įsteigti Aukštuju karininku kursai, o 1922 m. lapkričio 4 d. isakymu kariuomenei Nr. 242 priimtas kursu statutas, kuriame buvo numatytas Generalinio štabo skyrius. Tik paruošus pakankama kvalifikuotu su aukštuoju kariniu išsilavinimu karininku skaičiu, 1931 m. gen. P. Kubiliūno iniciatyva Kaune buvo ikurta aukštoji karo mokykla - Vytauto Didžiojo karininku kursu Generalinio štabo skyrius. Generalinio štabo kursu I laidos pradžia reikètu laikyti $1931 \mathrm{~m}$. sausio $22 \mathrm{~d}$., kada pasirodè Vyriausiojo štabo aplinkraštis Nr. 46049, skelbiantis apie numatoma Generalinio štabo kursu
\end{abstract} steigima ir nustatantis kursu kandidatams stojimo sąlygas.

Visus pagrindinius karinius dalykus dèstè Generalinio štabo karininkai, baige mokyklas užsienyje. Déstant pagrindinius dalykus, buvo laikomasi principo, kad lektoriai būtu baige ta pačia užsienio karo mokyklą. Tam tikru pagrindiniu dalyku (bendroji taktika, Generalinio štabo tarnyba) lektoriai buvo etatiniai, o jiems talkino asistentai.

Visi Lietuvos generalinio štabo karininkai buvo baige Europos valstybiu aukštasias karo mokyklas. Tačiau ir isteigus $1931 \mathrm{~m}$. savają aukštają karo mokykla - Generalinio štabo skyrių - ryšiai su užsienio mokyklomis nebuvo nutraukti.

1938 m. gruodžio 10 d. LR Prezidento priimtas istatymas, pagal kurị Vytauto Didžiojo karininku kursai pavadinami Vytauto Didžiojo aukštają karo mokykla, kurios tikslas 1) suteikti karininkams aukštojo karo mokslo žiniu, 2) kurti ir tobulinti karo moksla ir jo rezultatus taikyti krašto salygoms ir poreikiams. Remiantis Vytauto Didžiojo aukštosios karo mokyklos įstatymo 27 str. (Vyriausybès žinios, 1938 m., Nr. 627), krašto apsaugos ministras brg. gen. K. Musteikis ir kariuomenès vadas brg. gen. S. Raštikis 1938 m. gruodžio 19 d. paskelbè Vytauto Didžiojo aukštosios karo mokyklos statutą.

Ši aukštoji karo mokykla rengè karininkus, kurie galètu dirbti Generaliniame štabe bei vadovauti dideliems kariniams daliniams. Aukštoji karo mokykla ypatingai vertinga dèl to, kad joje igyjamos žinios galèjo būti taikomos specifinèmis mūsu krašto sąlygomis. Joje jau buvo pradètos kurti naujos Lietuvai tinkamos karinès doktrinos. Spèta parengti 3 Generalinio štabo karininku (57 karininkai) ir 1 intendantu laida (7 karininkai). Ketvirtoji laida mokslo metus pradejo 1939 m.

Dar 1940 m. pradžioje pradèta rinkti Aukštosios karo mokyklos Generalinio štabo skyriaus penktoji laida, tačiau, prasidèjus sovietinei okupacijai, Vytauto Didžiojo aukštoji karo mokykla buvo uždaryta, daug absolventų ir dèstytoju ištremta i Sovietu Sajunga ar nužudyta.

Pagrindiniai žodžiai: Vytauto Didžiojo karininku kursu Generalinio štabo skyrius, Vytauto Didžiojo aukštoji karo mokykla. 


\section{Ivadas}

1921 m. balandžio 1 d. buvo įsteigti Aukštụjų karininkų kursai, o 1922 m. lapkričio 4 d. ịsakymu kariuomenei Nr. 242 priimtas kursų statutas, kuriame buvo numatytas Generalinio štabo skyrius. Tuo metu ir vèliau (iki $1927 \mathrm{~m}$.) jị organizuoti nebuvo galima, nes sąlygos Lietuvoje pirmaisiais nepriklausomybès metais nebuvo palankios savajai aukštajai karo mokyklai kurti: trūko patyrusių ir kvalifikuotu lektorių, neaukštas buvo karininkų intelektinis lygis, svarbiausia, kad bet kurị mokymąsi teko kelti ị antrą vietą, nes prioritetas buvo krašto gynimo reikalai ir sunkus kariuomenès kūrimo darbas. Tačiau, praejus maždaug dešimčiai metų, ši ir kitos problemos buvo sékmingai išspręstos. Aukštosios karo mokyklos steigimu rimtai susirūpinta tik $1927 \mathrm{~m}$.

Iki $1931 \mathrm{~m}$. Lietuvoje nebuvo aukštojo karo mokslo institucijos, todèl pasitobulinti arba ịgyti retesnių karinių specialybių atrinkti karininkai buvo siunčiami ị Prancūzijos, Vokietijos, Italijos, Belgijos, Anglijos, Austrijos, Čekoslovakijos karo akademijas intendantų, karo technikos, jūrų, kavalerijos mokyklas studijuoti aeronautikos, karo inžinerijos, radiotechnikos, elektrotechnikos, medicinos, veterinarijos, chemijos, mechanikos, meteorologijos, fizinio lavinimo ir kitų mokslų. Visi Generalinio štabo karininkai buvo baigę šių valstybių aukštąsias karo mokyklas. Be to, beveik kasmet keli karininkai atlikti stažuotę buvo siunčiamai ị užsienio valstybių kariuomenes. Be siuntimo ị užsienị Krašto apsaugos ministerija turèjo stipendininkų ir Vytauto Didžiojo universitete. Čia buvo ruošiami inžinieriai, gydytojai, mechanikai, teisininkai, chemikai ir veterinarai. Tačiau, ir ịsteigus $1931 \mathrm{~m}$. savają aukštają karo mokyklą - Generalinio štabo skyrių, - ryšiai su užsienio mokyklomis nebuvo nutraukti. Kaip ir iki tol ị užsienị buvo siunčiami karininkai, jau baigę Generalinio štabo kursus. Tai neleido nutolti nuo naujų karo idèjų, techninių išradimų ir pan., o tokiu būdu buvo rengiami lektoriai Generalinio štabo kursams.

Pasibaigus Nepriklausomybės kovoms, kai kariuomenès rengimas jau buvo tvarkomas planingai ir sistemingai, organizacinis darbas užleido vietą kitiems svarbesniems kariuomenès kūrimo klausimams spręsti.

Nuo $1921 \mathrm{~m}$. iki $1932 \mathrm{~m}$. kasmet mokytis į užsienio karo mokyklas buvo siunčiama po keletą karininkų ir už jų mokslą valstybė išleisdavo nuo 200000 iki 400000 litų.

Gen. štabo plk. K. Škirpos (1927 m. balandžio mèn.) nuomone, ,šiuo būdu mes savo štabų tinkamais specialistais niekad neapsirūpinsime. Skaitant, kad kasmet grịš 1-3 karininkai, gerai baigę mokslus, mes galètume šiuo būdu paruošti reikiamą Generalinio štabo karininkų skaičių ne greičiau kaip per 30-40 metų. Per tiek laiko nemažai baigusių spès visai išeiti iš karo tarnybos, o kiti, karo menui nuolat darant pažangą, bus reikalingi dẻl mokslo žinių atnaujinimo ir t. t. Tuo tarpu mūsų gyvenimo sąlygos, būtent nuolatinis karo pavojus, reikalauja, kad mūsų kariuomenei reikiamą Generalinio štabo karininkų skaičių paruoštume kiek galint greičiau ir būtų idealas juos turèti dabar... Pagaliau, dar reikia pažymèti, kad komandiruo- 
ti į užsienius karininkai besimokydami atitolsta nuo Lietuvos gyvenimo ir, baigę mokslus, pargrịžę i savo kraštą ne tuojau gali sèkmingai dirbti jiems pavestą darbą. Be to, kadangi jie komandiruojami ne ị vieną vietą, ne ị vieną mokyklą, bet ị ịvairias šalis ir mokyklas, tai tarp baigusių kartais pasireiškia pažiūrų nevienodumas, kas sukelia nereikalingų diskusijų ir net asmeninių nesusipratimų, kurie iš savo pusès pagimdo nesantaiką vadovybëje, kas yra labai žalinga tarnybai.

$<\ldots>$ Mano nuomone, reikia neatidèliojant steigti savo aukštąą karo mokyklą bei karo akademiją. Tai vienintelis racionaliausias klausimo išsprendimas. Minètos karo akademijos tikslas būtų paruošti tinkamą štabo tarnybai specialistų ir kandidatų skaičių aukštesniosioms vadovybès vietoms užimti ir suteikti mūsų karininkams aukštojo karo mokslo žinių. Dabartiniai mūsų Aukštieji karininkų kursai šių uždavinių atlikti negali, nes kursų tikslas - tobulinti rikiuotès karininkus ir ruošti ginklų rūšių specialistus.

Antra, atsižvelgiant ị mūsų gyvenimo sąlygas, kada mūsų kariuomenè tebẻra organizacijos ir visokių bandymų stadijoje - karo akademija galètų tapti Generalinio štabo laboratorija, kur pavidale referatų ir gilesnių studijų prie progos galètų būti išstudijuotos ir išanalizuotos įvairios mūsu ginkluotosios jègos bei krašto gynimą liečiantieji klausimai, kaip yra kitose šalyse.

$<\ldots>$ Iš visa to ir seka išvada, kad reikia neatidèliojant imtis mūsų aukštosios karo mokyklos steigimo. Praktiškai šis sumanymas yra įvykdomas. Tų 200000 litų, kuriuos valstybė kasmet išleidžia komandiravimui karininkų ị užsieni ne tik užtektų, bet dar būtų perdaug aukštajai karo mokyklai išlaikyti Lietuvoje. Profesūros specialiems karo mokslo dalykams dèstyti mes taip pat jau turime, o bendro lavinimo dalykams dèstyti (ne karo) - galètume pakviesti keletą universiteto profesorių. Pagaliau, kad sumažintume administracijos išlaidas, ši aukštoji karo mokykla galètų tikti prie Aukštųų karininkų kursų, pavidale Generalinio štabo skyriaus, kaip tatai seniau buvo manyta padaryti." (Kardas, 1927, Nr. 13-14 (73-74), p. 180-182).

1927 m. balandžio 27 d. Gen. štabo plk. K. Škirpa raporte krašto apsaugos ministrui plk. A. Merkiui rašè: „, $<>>$ Norint Generalio (generalinio) štabo karininkų paruošimą pagreitinti, reikia neatidèliojant steigti savo aukštają karo mokyklą, kurios tikslas būtų: 1) paruošti Generalio štabo karininkus, 2) paruošti kandidatus i aukštesnes vadovybès vietas, 3) bendrai platinti aukštojo karo mokslo žinias karininkų tarpe.

I užsienị būtų galima kasmet ar laikotarpiais komandiruoti po kokị 1 karininką, jau baigusị mūsų aukštają karo mokyklą, palaikymui ryšių su užsienio karo akademijomis $<\ldots>$.

$<\ldots>$ Tuo tarpu, kad negaišinus brangaus laiko, būtu galima užsiimti savu Generalio štabo karininkų paruošimu, tam tikslui komplektuoti Aukštujų karininkų kursų Generalio štabo skyrių, kurio organizavimui priešingų motyvų nėra.

Prireikus vyresniųų viršininkų paruošimas galètų eiti lygiagrečiai su Generalio štabo skyriaus pirmaja laida, būtent kai ši pastaroji eis antrus mokslo metus.

Kai dèl lèšų, tai jų rasis, nes bendrosios Aukštụjų karininkų kursų laidos ši 
rudenị rinkti neįmanoma.

Generalio štabo skyriaus laidą reiketų surinkti š. m. lapkričio $1 \mathrm{~d}$. Neatsižvelgiant ị visą tai, kas buvo aukščiau išdèstyta, prašau Tamstos principinio nusistatymo ir parèdymo Aukštųjų karininkų kursų Generalio štabo skyriaus komplektavimo reikalu, kad, gavus Tamstos sutikimą, Vyriausiasis štabas galètų neatidèliojant imtis paruošiamojo darbo šiam sumanymui igyvendinti." (Lietuvos centrinis valstybinis archyvas (toliau - LCVA), f. 929, ap. 6, b. 94, 1. 110).

Tyrimo objektas - Vytauto Didžiojo aukštoji karo mokykla (1931-1940 m.).

Tyrimo tikslas - atskleisti Vytauto Didžiojo aukštosios karo mokyklos veiklą 1931-1940 m.

\section{Tyrimo uždaviniai:}

Aptarti Vytauto Didžiojo aukštosios karo mokyklos raidą 1931-1940 m.

Apžvelgti ir ịvertinti Vytauto Didžiojo aukštosios karo mokyklos studijų procesą, mokyklos reikšmę Lietuvos kariuomenei.

Tyrimo metodai - remiantis Lietuvos archyvinių šaltinių, mokslinès literatūros ir periodinès spaudos analize, taikant istorini, chronologinị tyrimo metodus, straipsnyje nagrinejjama Vytauto Didžiojo aukštosios karo mokyklos raida. Straipsnyje ištirtą prieškarinę patirtị bus naudinga panaudoti organizuojant ir tobulinant šiuolaikinę karininkų rengimo ir jų kvalifikacijos kèlimo sistemą.

\section{Vytauto Didžiojo karininkụ kursų Generalinio štabo skyrius}

Susidarius tokiai situacijai, buvo nuspręsta steigti savo aukštojo karo mokslo instituciją. Reikia pažymèti, kad dar 1922 m. spalio 23 d. paskelbtame Aukštujų karininku kursu statute yra kalbama apie Generalinio štabo skyriaus steigimą. Statutas buvo neigyvendintas ta prasme, kad jame minimas Generalinio štabo karininku korpusas buvo nesudarytas. Be to, Aukštieji karininkų kursai pagal savo paskirtị ir mokymo programą neprilygo aukštosios karo mokyklos statusui, todèl ir Generalinio štabo skyrius nesiderino su kitais kursų skyriais.

1927 m. balandžio 28 d. ir gegužès 10 d. Aukštujjų karininkų kursų viršininkas Gen. štabo gen. L. Radus-Zenkavičius raportuose Vyriausiojo štabo viršininkui plk. T. Daukantui rašo, kad jau atèjo laikas įsteigti Generalinio štabo skyrių, nes: 1) Didžiojo Lietuvos kunigaikščio Vytauto aukštieji karininkų kursai taip sustiprèjo, kad visiškai pajègs sudaryti Generalinio štabo skyrių; 2) jau yra pakankamai lektorių ir instruktorių, igijusių aukštaji karo mokslą; 3) neturint Generalinio štabo kursų, labai sunku bus: a) suvienodinti skirtingas pažiūras, kurios dabartiniu metu reiškiasi tarp karininkų, baigusių įvairių valstybių kursus; b) galutinai nustatyti karo doktriną ir ją igyvendinti kariuomeneje; 4) be Generalinio štabo kursų nebus galima sudaryti taip mums reikalingo, gerai ir vienodai išlavinto ir mūsų sąlygoms tinkamo Generalinio štabo karininkų korpuso.

Generaliniame štabo skyriuje turejo būti dėstomi šie dalykai: specialūs karo dalykai - 1) strategijos sintezè, 2) karo menas, karo istorija, 3) Lietuvos karo isto- 
rija, 4) Generalinio štabo tarnyba, 5) bendroji taktika, 6) pėstijos taktika, 7) artilerijos taktika, 8) kavalerijos taktika, 9) aviacija, 10) cheminis karas, 11) žinių tarnyba, 12) ryšiai, 13) fortifikacija, 14) karo administracija, 15) tarnybų organizacija ir funkcionavimas, 16) artilerija; nespecialūs karo dalykai - 1) karo finansavimas, 2) šalies resursų mobilizacija, 3) karo politika, 4) psichologija, 5) karo geografija, 6) taikomieji mokslai, 7) topografija; civiliniai dalykai - 1) politinè istorija, 2) valstybinè teisé, 3) tarptautinè teisè, 4) politinè ekonomija, 5) užsienio kalba.

1928 m. išlaidos numatomos (mokant už septynių mėn. metodini kursą 40 tūkst. Lt, praktikos darbus - 15 tūkst. Lt, bibliotekai - 10 tūkst. Lt, braižyklai (schemos ir kt.) - 8 tūkst. Lt, paskaitų spausdinimas - 30 tūkst. Lt. Iš viso išlaidų 103 tūkst. Lt.

Iki šiol Aukštujų karininkų kursų D. L. K. Vytauto kursų Bendram skyriui buvo asignuojama: $1924 \mathrm{~m}$. mokymui - 75 tūkst. Lt, bibliotekai -2 tūkst. Lt, braižyklai - 6 tūkst. Lt.; 1925 m. atitinkamai - 79 tūkst. Lt, 2 tūkst. Lt ir 3 tūkst. Lt.

Generalinio štabo kursų lěšos, skiriamos leidiniams, galèjo sumažèti, nes spaudos dalies išlaidas peremė kursai. Kadangi 1928 m. nebuvo organizuojama Bendrojo skyriaus eilinè laida, daugiau išlaidų nebuvo nenumatyta (LCVA, f. 1451, ap. 1, b. 33, 1. 11, 13).

Kaip minèta, 1927 m. prasideda paruošiamasis darbas steigti Generalinio štabo skyriu. Antai 1927 m. liepos 27 d. Ministras Pirmininkas ir laikinai einantis krašto apsaugos ministro pareigas prof. A. Voldemaras ir vyriausiojo štabo viršininkas plk. T. Daukantas pasirašè įsakymą kariuomenei Nr. 92, kuriame skelbiama, kad, remiantis Aukštujų karininkų kursų statuto 1 ir 2 str., prie Aukštujų karininkų kursų nuo 1927 m. gruodžio 1 d. pradeda veikti Generalinio štabo skyrius. Iki rugpjūčio 10 d. dalių vadai pristato apygardų viršininkams kandidatų sąrašus ne daugiau kaip po 5 iš kiekvienos dalies, vadovaudamiesi pridedama instrukcija ir asmens lapų forma Nr. 2. Iš pristatytų kandidatų sąrašų apygardų viršininkai tvirtina tuos, kuriuos laiko tinkamais, ir apygardų štabuose sudarytus sąrašus pristato Vyriausiojo štabo viršininkui iki rugpjūčio 25 d. Vyriausiojo štabo viršininko patvirtintiems kandidatams gruodžio 1-10 d. organizuojami egzaminai iš šių dalykų: raštu - matematika, lietuvių kalba, taktika (iki bataliono), istorija (Lietuvos ir XIX a. bendroji), geografija, logika ir psichologija, statutai. Iš visų dalykų, išskyrus taktiką ir statutus, reikalaujamas „Aušros“ gimnazijos kursas iš atitinkamų vadovèlių.

Sprendžiant iš Lietuvos centrinio valstybinio archyvo dokumentų, tarpukario publikacijų karine tematika, Aukštieji karininkų kursai nustojo veikti apie 1930-1933 m.

Tik paruošus pakankamą kvalifikuotų su aukštuoju kariniu išsilavinimu karininkų skaičių, 1931 m. gen. P. Kubiliūno iniciatyva Kaune buvo įkurta aukštoji karo mokykla - Vytauto Didžiojo karininku kursu Generalinio štabo skyrius (Kardas, 1937, Nr. 8 (262), p. 185).

Generalinio štabo kursai turejo ir savo ypatumų, kurie juos skyrè nuo analogiškų užsienio mokyklų. Pirmiausia, tai - grynai lietuviška mokykla, vadinasi, 
kariuomenès rengimas karui ir tobulinimas, kiekvienas kvalifikacijos kèlimas buvo skirtas krašto gynimui.

Šios aukštosios karo mokyklos tikslas (kaip numatyta mokymo plane) - parengti kariuomenei kvalifikuotų karininkų, suteikiant jiems ne tik specialių ir bendrų žinių, bet ir atitinkamo karinio suvokimo (mastymo) metodą. Karininkas, baigęs kursus, turejjo sugebėti savarankiškai spręsti visas problemas, susijusias su valstybès saugumu, ir būti visapusiškai pasirengęs tam darbui, t. y. tikti Generalinio štabo tarnybai. Be to, baigęs kursus, karininkas po atitinkamo tarnybos stažo ir praktikos turèjo sugebèti sẻkmingai vadovauti visų ginklų rūšių stambesniam junginiui, t. y. kursu tikslas - rengti ne tik štabo karininkus, bet ir vadus.

Taip pat karininkas turejjo sugebèti vadovauti ir instruktuoti įvairias taktines pratybas auditorijoje ir lauke, o prireikus būti dar ir taktikos vadovu - instruktoriumi; ruošti kariuomenei reikalingus statutus, o veikiančius - tobulinti. Buvo tikimasi, kad Generalinio štabo kursai bus taja protine „laboratorija“, kurioje kristalizuosis karo doktrina ir kariško mintijimo idejos, vedant moksliškas studijas įvairiais kariškais klausimais.

Siekiant užsibrežto tikslo, Generalinio štabo kursuose turèjo vyrauti karinès tematikos dalykai, kurie daugiausiai rèmèsi vadovavimo principais tikrose karo sąlygose. Be karinių dalykų kursuose turejjo būti dèstomi ir bendro pobūdžio dalykai, kurie tampriai turèjo sietis su kariniais klausimais ir padèti plèsti būsimų Generalinio štabo karininkų akiratị valstybingumo ir valstybės saugumo klausimais. Užsienio kalbų desstymas turejo suteikti klausytojams galimybę savarankiškai naudotis užsienio karine literatūra.

Generalinio štabo kursai vykdys didelị tobulinimo ir pažiūrų vienodinimo darbą, todèl kai kuriems teorijos ir praktikos dalykams studijuoti bus pakviesti ir kai kurių tarnybų karininkai, pavyzdžiui, intendantai, sanitarijos karininkai ir t. t. (Kardas, 1932, Nr. 5 (37), p. 66-67; Jodauga J., p. 84.).

Generalinio štabo kursų I laidos pradžia reikètų laikyti $1931 \mathrm{~m}$. sausio $22 \mathrm{~d}$., kada pasirode Vyriausiojo štabo aplinkraštis Nr. 46049, skelbiantis apie numatomą Generalinio štabo kursų steigimą ir nustatantis kursų kandidatams stojimo sąlygas: „1932 m. pradžioje prie Vytauto Didžiojo karininkų kursų numatoma steigti Generalinio štabo kursus. Mokslas tęsis du metus. Baigusiesiems bus suteiktos visos teisès, numatytos baigusiesiems Generalinio štabo akademiją. “

İ šiuos kursus karininkų klausytojų prièmimas buvo numatomas konkursinio egzamino būdu. Prie konkursinių egzaminų buvo ketinama prileisti tuos karininkus, kurie turèjo ne aukštesnị kaip majoro laipsnị; iki $1932 \mathrm{~m}$. sausio $1 \mathrm{~d}$. turèjo ne daugiau kaip $35 \mathrm{~m}$; per paskutinius tris metus buvo gerai atestuoti; sveikatos būklè - tinkama rikiuotei.

Išimties būdu ị šiuos Generalinio štabo kursus galèjo kelti savo kandidatūrą ir tie karininkai, kurie, kad ir ne visai atitinka čia paskelbtas sąlygas, tačiau dalyvavo Pirmajame pasauliniame kare ar Nepriklausomybès karuose ir turi kautyniu patirties ar tarnybinių nuopelnų. Apie jų prileidimą prie konkursinių egzaminų turejjo 
spręsti Vyriausiojo štabo viršininkas. Konkursiniai egzaminai buvo numatyti dviem etapais: pavasarị ir rudeni (LCVA, F. 929, ap. 6, b. 126, 1. 11).

Pavasario konkursiniuose egzaminuose dalyvavo 32 kandidatai (2 kandidatai priimti ị kursus be egzaminų, nes juos išlaikè anksčiau). Pavasario laikotarpis gegužès pirmoje pusėje, o rudens - lapkričio antroje pusejje. Pavasario egzaminai: taktika (žodžiu ir raštu), geografija (raštu) ir topografija (raštu). Rudens egzaminams skiriama (kariuomenès manevrams pasibaigus) visuotinè istorija (žodžiu), karo istorija (žodžiu) ir pasirinktinai dvi kalbos (rusų, vokiečių, lenkų, prancūzų). Egzaminų programa ir koeficientų skirstymas vykdomas remiantis Generalinio štabo 1930 m. lapkričio 12 d. aplinkraščiu Nr. 24093.

Tarp pavasario ir rudens egzaminų bus atliekamos sėkmingai pavasario egzaminus išlaikiusių kandidatų rikiuotės pratybos. Iš veikiančių Aukštujjų karininkų kursų kandidatai toliau tęsė mokslus. Jų tarnybos stažas buvo tvarkomas atskiru potvarkiu.

Apie galutinị Generalinio štabo kursų sudètị turejjo spręsti Vyriausiojo štabo viršininkas, remdamasis pavasario, rikiuotės stažo ir rudens egzaminų rezultatais.

Egzaminų pradžia, jų tvarkaraštis, egzaminų komisijų sudètis ir prie konkursinių egzaminų prileistų karininkų sąrašas turèjo būti skelbiamas atskirai. Dalių vadams ir įstaigų viršininkams Vyriausiojo štabo viršininkas įsakè iki $1931 \mathrm{~m}$. balandžio 1 d. pateikti Generalinio štabo valdybai karininkų, norinčių įstoti ị Generalinio štabo kursus, sąrašus. Prie sąrašo privalo būti pridèti įsakymu kariuomenei Nr. 56 (1930 m. lapkričio 15 d. III dalies 6 punkte) numatyti dokumentai (LCVA, F. 929 , ap. 6, b. 126, 1. 11).

Egzaminai prasidejo birželio 8 d. Oficialia kursų pirmos laidos pradžia galima laikyti $1931 \mathrm{~m}$. birželio $20 \mathrm{~d}$., nes tą dieną kandidatai daliniuose ir įstaigose (pèstininkų, artilerijos, aviacijos, kavalerijos, technikos daliniuose, specialiuose kursuose, poligone, Vyriausiajame štabe) pradèjo atlikti stažuotę, kuri tęsėsi iki 1932 m. kovo 31 d. ( LCVA, f. 1451, ap. 1, b. 74, 1. 57; Kardas, 1934, Nr. 11 (188), p. 214-215).

Tinkamai pasiruošus, $1932 \mathrm{~m}$. kovo $10 \mathrm{~d}$. įsakyme kariuomenei Nr. 20 teigiama, kad, remiantis Vytauto Didžiojo karininkų kursų statutu, nuo 1932 m. balandžio 1 d. organizuojamas Aukštujų karininkų kursų Generalinio štabo skyrius, vadinamas Generalinio štabo kursais (str. 1). Buvo ịsteigta aukštoji karo mokykla - Vytauto Diď̌iojo karininku kursų Generalinio štabo skyrius. 1938 m. gruodžio 10 d. jis pavadintas Vytauto Didžiojo aukštaja karo mokykla. Veikè ịvairūs laikinieji kursai, kurie buvo steigiami tiesiogiai prižiūrint ginklų rūšių viršininkams ar prie Karo mokyklos (LCVA, f. 384, ap. 1, b. 99, 1. 136, b. 103, 1. 39).

Generalinio štabo kursų bendra priežiūra priklauso Vyriausiojo štabo viršininkui (2 str.). Vyriausiojo štabo viršininkas nustato steigiamiesiems kursams mokymo tikslus, metodus, programas, pristato krašto apsaugos ministrui tvirtinti kiekvienos naujos laidos mokymo personalo bei klausytojų sudètị ir skaičių ir bendrai tvarko kursų mokomają kryptį, teikia Vytauto Didžiojo karininkų kursų viršininkui 
reikalingus nurodymus ( 3 str.).

Ūkio atžvilgiu Generalinio štabo kursus aprūpina (patalpomis, kuru, apšvietimu, išorès apsauga, ir bendrai visu tuo, kas yra susieta su patalpų tinkama būkle) Vyriausiojo štabo ūkio skyrius. Visais kitais ūkio reikalais rūpinasi Vytauto Didžiojo karininkų kursai (4 str.). Generalinio štabo kursų buveinè - Kaunas, Miškų g. Nr. 22 (5 str.).

Skelbiama, kad 1931 m. įsakyme kariuomenei Nr. 51, 9 str., išvardinti karininkai kandidatai (24 karininkai kandidatai) ị Generalinio štabo kursus atliko įvairiose kariuomenès dalyse taktikos pratybas nuo $1931 \mathrm{~m}$. birželio $20 \mathrm{~d}$. iki gruodžio $14 \mathrm{~d}$.

Karininkai kandidatai į Generalinio štabo kursus nuo $1931 \mathrm{~m}$. gruodžio 15 d. iki $1932 \mathrm{~m}$. sausio $19 \mathrm{~d}$. buvo paleisti kaledinių atostogų. Nuo sausio $20 \mathrm{~d}$. iki $29 \mathrm{~d}$. Vytauto Didžiojo karininkų kursuose laikè rudens egzaminus (str. 6).

20 karininkų, išlaikę Generalinio štabo kursų egzaminus (plk. V. Giedrys, plk 1tn. K. Sprangauskas; majorai - V. Kiršinas, A. Čepauskas, P. Budraitis, A. Urbšas, B. Gertus, L. Rupšys; kapitonai - A. Sperauskas, J. Listopadskis, K. Pranckevičius, P. Ličkus, J. Liūga, A. Špokevičius, P. Matulis, A. Jonaitis, J. Purelis, V. Motieka, J. Ivašauskas, J. Jodauga), laikomi Generalinio štabo kursų klausytojais ir nuo $1932 \mathrm{~m}$. vasario $1 \mathrm{~d}$. iki kovo $19 \mathrm{~d}$. komandiruojami ị Generalinio štabo valdybą atlikti stažą (7 str.). Generalinio štabo kursų pirmos laidos mokslo metų pradžia $1932 \mathrm{~m}$. balandžio 1 d. (8 str.).

Kandidatas ị Generalinio štabo kursus I-ojo husarų Didžiojo Lietuvos Etmono kunigaikščio Jonušo Radvilos pulko kpt. S. Gudauskas 1931 m. lapkričio 10 d. susirgo ir buvo paguldytas ị karo ligoninę. Dél ligos ị Generalinio štabo kursus nepriimtas (9 str.).

Papildant 1931 m. įsakymą kariuomenei Nr. 39, 4 str. skelbiama, kad kandidatų ị Generalinio štabo kursus, remiantis egzaminų rezultatais, 9-jo pėstininkų Lietuvos kunigaikščio Vytenio pulko kpt. T. Kuktos, Ryšių bataliono kpt. J. Šepečio ir 2-jo pestininkų Didžiojo Lietuvos kunigaikščio Algirdo pulko 1tn. V. Kiršino Generalinio štabo kursų pavasario egzaminai išlaikyti ir įskaitomi su sąlygomis įgyti kitą laipsnị (10 str.). Pasirašè krašto apsaugos ministras plk. B. Giedraitis ir Vyriausiojo štabo viršininkas gen. ltn. P. Kubiliūnas ( LCVA, f. 384, ap. 1, b. 103, 1. 39).

Pirmieji Generalinio štabo kursų mokslo metai prasidèjo $1932 \mathrm{~m}$. balandžio 1 d. naujai suremontuotose buvusiose pašto valdybos patalpose. Kuklios iškilmès prasidejo krašto apsaugos ministro plk. B. Giedraičio kalba, kuris pasveikino susirinkusiuosius, iškẻlè naujos mokyklos svarbą Lietuvos kariuomenei ir visam kraštui bei perdavė Respublikos Prezidento ir savo linkejjimus sẻkmingai dirbti sunkų ir garbingą darbą. Vèliau kursų vadovas gen. 1tn. P. Kubiliūnas perskaitė izžanginę paskaitą, kurioje apžvelge aukštosios karo mokyklos paskirtị ir kryptis, kuriomis jai teks dirbti. Krašto apsaugos ministrui pasiūlius, pirmosios laidos darbas buvo pradètas visiems dalyviams sugiedojus himną. Tuomet ịvyko mažo masto imatrikuliacija: kursų vadovas krašto apsaugos ministrui pristatẻ pirmos laidos kiekvie- 
ną klausytoją atskirai. Vèliau taktikos lektorius gen. 1tn. J. Jackus skaitè paskaitą „Pèstininkų manevras ir jo elementai“, kurioje dalyvavo krašto apsaugos ministras, kursų vadovas, visi lektoriai ir svečiai ( Kardas, 1932, Nr. 5 (37), p. 67).

Pirmają laidą sudare 20 klausytojų. Visi klausytojai buvo baigę aukštesniają mokyklą, dauguma - Lietuvos karo mokyklos auklètiniai (15). Mokslas truko tris metus. Pirmieji mokslo metai prasidejjo $1932 \mathrm{~m}$. balandžio $1 \mathrm{~d}$. ir baigèsi $1933 \mathrm{~m}$. kovo 29 d., antrujų pradžia -1933 m. balandžio 19 d., pabaiga - 1934 m. gegužès $14 \mathrm{~d}$. Kursas baigèsi svarbesnių dalykų egzaminais ir taktine ekskursija. Mokslo metai buvo skirstomi i tris trimestrus.

Studijų diena prasidedavo paprastai - jodinejjimo pamoka husarų pulko maniežo aikštėje. Vèliau vyko mokymo procesas auditorijose pagal numatytą tvarkaraštic. Apskritai, reikia pažymèti, kad klausytojų studijų dienos nebuvo galima tiksliai nustatyti valandomis, nes, išejus iš auditorijos, ji tęsèsi ir namuose: visada reikejo pasiruošti kitai dienai. Dienomis, kada vyko lauko pratybos, karo žaidimai, mokymas užtrukdavo ilgokai. O kur terminuoti rašto darbai, kurie kartais trūko po dvi savaites? (Kardas, 1934, Nr. 11 (188), p. 215).

Vytauto Didžiojo karininkų kursų Generalinio štabo skyriui 1933 m. buvo numatyta pedagoginiam darbui skirti 27,719 tūkst. Lt: specialūs dalykai - teorijos paskaitos (306 val.), eksperimentinès valandos ir rašto darbai (404 val.), kombinuoti darbai, karo žaidimai, lauko kelionès, egzaminai ir t. t. (292 val.); bendri dalykai - teorinès valandos (275 val.), jodinëjimas (145 val.) (LCVA, f. 1451, ap. 1, b. $31,1.9)$.

Vyriausiojo štabo viršininko ir Generalinio štabo kursų pirmojo viršininko gen. ltn. P. Kubiliūno vaidmuo reiškèsi nuolatiniu ir glaudžiu vadovavimu kursams, mokomojo proceso tvarkymu, mokymo plano vykdymo kontrole ir priežiūra. Dar galutinai nesusiformavus lietuviškajai karo doktrinai, gen. P. Kubiliūnui mokslo metų eigoje teko nurodinèti šios doktrinos gaires, vienodinti kartais pasireškiančias skirtingas pažiūras. Kursų viršininko patariamasis organas buvo pedagogų taryba, kurios sudètis ir pagrindinių dalykų programos kiekvieną kartą buvo atskirai nustatomos.

Pagrindinę visų dėstytų dalykų grupę sudare bendroji, ịvairių ginklų rūšių taktika (pėstininkų, artilerijos, kavalerijos, aviacijos ir t .t.) ir Generalinio štabo tarnyba. Panašiai kaip ir užsienio valstybių tokio tipo mokyklose šios grupès pagrindą sudare bendroji taktika; antrą grupę - karo istorija, karo geografija, žinių rinkimas, užsienio valstybių kariuomenių organizacija, kariavimo dèsniai, ginklavimas, technikos priemonès ir kt., mobilizacija, geležinkeliai, šalies krantų apsauga; trečią grupę - bendrojo pobūdžio dalykai: valstybinè ir tarptautinè teisè, ekonomikos mokslu pagrindai, diplomatijos istorija, eksperimentinè ir karo psichologija, užsienio (lenkų, vokiečių) kalbos ir jodinëjimas.

Visus pagrindinius karinius dalykus dèstė Generalinio štabo karininkai, baigę mokyklas užsienyje. Dėstant pagrindinius dalykus, buvo laikomasi principo, kad lektoriai būtų baigę tą pačią užsienio karo mokyklą. Tam tikrų pagrindinių dalykų 
(bendroji taktika, Generalinio štabo tarnyba) lektoriai buvo etatiniai darbuotojai, o jiems talkino asistentai.

Antraisiais mokslo metais buvo dèstomas ištisas teisès ir visuomenès mokslų ciklas, kurị skaitė Vytauto Didžiojo universiteto profesoriai: M. Romeris - Valstybinę teisę, V. Jurgutis - Politinę ekonomija, A. Jaščenka - Tarptautinę teisę; Užsienio reikalų ministerijos Tautu Sajungos referentas dr. L. Natkevičius - Diplomatinę istoriją. Šių dalykų kursas pagrindiniais bruožais sutampa su Vytauto Didžiojo universiteto dėstomais dalykais, nors kiek koncentruotas ir sutrumpintas, kur visi dalykai, ne tokie svarbūs karių auditorijai, yra eliminuoti.

Šias paskaitas, kaip turinčias platesnę reikšmę, klausè ne tik Generalinio štabo kursų klausytojai, bet ir kiti Kauno karininkai, kuriems dẻl jų tarnybos pobūdžio teko susidurti su teisès ir visuomenès mokslų aktualijomis ir problemomis. Pirmoji tokios paskirties paskaita įvyko $1933 \mathrm{~m}$. spalio $5 \mathrm{~d}$. Generalinio štabo kursu patalpose, dalyvaujant Vyriausiojo štabo viršininkui, - prof. A. Jaščenka pradejjo Tarptautines teisès kursą. Tam tikras pratybas vesti, taip pat vadovauti karo žaidimams, taktinėms kelionėms be nuolatinių lektorių būdavo kviečiami ir kiti karininkai (Kardas, 1933, Nr. 11 (173), p. 215; Kardas, 1934, Nr. 11 (188), p. 215).

Vytauto Didžiojo karininkų kursų Generalinio štabo skyrius mokymo programa prilygo kitų valstybių generalinių štabų akademijų programoms. Kaip ir užsienio generalinio štabo mokyklose, taip ir Lietuvos Generalinio štabo kursų mokymo pagrindą sudare eksperimentinis metodas. Bendroje bei įvairių ginklų rūšių taktikoje ir Generalinio štabo tarnyboje vyravo konkrečiu taikomujų taktinių pratybu praktika. Teorijai tik tiek buvo skiriama vietos, kiek būtinai reikejjo, o visa medžiaga desstoma pratybų metu. Taikomosios pratybos atliekamos klaseje ir lauke; be to, užduodami ịvairūs klasės bei namų rašomieji darbai ir t. t. Visas mokymo procesas baigdavosi karo žaidimais, o mokslo metų pabaigoje vykdavo taktinè kelionè. Pvz., 1933 m. taktinė ekskursija vyko Alytaus apylinkèse, o 1934 m. - Klaipėdos krašte (Kardas, 1934, Nr. 11 (188), p. 220-222; Kardas, 1934, Nr. 11 (188), p. 216).

1934 m. gegužès 18 d. ịvyko iškilmingos Generalinio štabo pirmosios laidos išleistuvès. Kad ši diena buvo aukštai vertinama, matyti iš Respublikos Prezidento, Vyriausybės ir aukštosios karo vadovybès apsilankymo ir jų pasisakymų.

Respublikos Prezidento 1934 m. gegužès 18 d. aktu Nr. 385 Vytauto Didžiojo karininkų kursų Generalinio štabo skyriaus pirmoji laida vadinama Respublikos Prezidento Antano Smetonos generalinio štabo kursu laida. Naujiesiems Generalinio štabo karininkams buvo įteikti diplomai ir kursų baigimo ženklai, kuriuos sukomponavo plk. V. Vitkauskas.

Vytauto Didžiojo karininkų kursų Generalinio štabo skyriaus Respublikos Prezidento A. Smetonos (pirmają) laidą baigė 18 karininkų: plk. V. Giedrys, plk. ltn. K. Sprangauskas; majorai - V. Kiršinas, A. Čepauskas, A. Urbšas, B. Gertus, L. Rupšys; kapitonai - A. Sperauskas, J. Listopadskis, K. Pranckevičius, P. Ličkus, A. Špokevičius, P. Matulis, A. Jonaitis, J. Purelis, V. Motieka; leitenantai J. Ivašauskas, J. Jodauga; ir visiems, išskyrus kpt. P. Ličkų ir kpt. A. Jonaiț, suteik- 
tos Generalinio štabo karininkų teisès (LCVA, f. 384, ap. 1, b. 111, 1. 12).

Respublikos Prezidentas A. Smetona Generalinio štabo pirmos laidos išleistuvių proga kalbejjo: „Šiandien, mielieji karininkai, yra didi švente jūsų, mano ir karinès vadovybès. Nors ją minime savybejje, tačiau prilygsta ji kitoms mūsų tautos šventėms. Juk tai labai svarbus ịvykis Lietuvai susilaukti pirmos aukštojo mokslo karininkų laidos iš savo aukštosios karo mokyklos. Kad ir nesivadina skambiu akademijos vardu, ji betgi atstoja mums tolygias kitų kraštų mokslo įstaigas. Savo žemèje savo priemonèmis ịgytos žinios ginklo pajègai vadovauti geriau tarnauja mūsų šalies saugumo tikslui.

$<\ldots>$ Didi ir prakilni priedermè mokyti savo tautos jaunimą ginklą vartoti, jaunujų kareivių būdą stiprinti. Visų pripažinta tiesa, tiesa ir reikalavimas, kad kareivis grižtu iš kariuomenès namon geresnis, ne kaip prieš tai būdamas savo šeimoje, artimujų tarpe. Tik iš taip auklejjamų kareivių gali susidaryti stipri ir neįveikiama kariuomenè. Svarbu žinios, bet dar svarbiau, vadinas, žmogaus būdas. Jị tvirtinti rūpinkitès, mielieji karininkai. Pavesdama savo jaunimą auklèti, tauta paveda jums savo buitį, savo ateitį. Štai kiek daug jums yra įtikèta, kiek daug vilties deda tauta aukštajai kariuomenès vadovybei $<\ldots$... .

Iškilmingų išleistuvių metu krašto apsaugos ministras plk. B. Giedraitis kalbejjo: „Ši diena reikšminga visai kariuomenei, nes nuo šios dienos ị kariuomenę įsilieja naujas Gen. štabo karininkų kadras, parengtas mūsų aukštojoje kariškoje mokykloje.

Iki šiolei dalis karininkų buvo siunčiami į užsienius. Ten mokslus baigę, jie virto lektorių kadru mūsų Gen. štabo kursams, o per jų darbą šiandien išleidžiame savo I laidą.

$<\ldots>$ Mūsų kariuomenè turi būti tautiška, turi surasti tautiškus tikslus ir norus. Greta kariškojo mokslo turi būti skiepijami ir ugdomi drausmè, tèvynès meilé, savo krašto pamėgimas. Čia - kiekvieno karininko darbo sritis“.

Po to kalbėjo Generalinio štabo kursų viršininkas gen. 1tn. P. Kubiliūnas: „<..> Mums atgijusioje Lietuvoje tenka kurti savo kariuomenę technikos ir didelès pažangos laikais. Dèl ịvairumo ir sudètingumo priemonių, dabar vartojamų kautynèse, kiekvienam karininkui reikia didelio pasirengimo ir daug žinių <...> .

Tokiam darbui pasirengti ir buvo organizuoti šie Generalinio štabo kursai. Tokios mokyklos reikalingumas buvo suprastas jau prieš 12 metų, bet dèl ịvairių priežasčių darbas nebuvo pradètas.

Dabar, kai mūsų kaimynai - lenkai, latviai, estai ir suomiai - švenčia savo karo akademijų dešimtmeti, mes teturime tik pirmosios laidos išleistuves. Bet pirmasis žingsnis nužengtas, tolesnis darbas bus varomas dar su didesniu pasiryžimu, ir mes tikri, kad ir karo mokslo srity mes susilyginsime su kaimynais ir turèsime mums prideramą vietą. Ši laida pavadinta Prezidento Smetonos vardu, nes iš pono Prezidento mes susilaukèm ypatingos paramos savo sunkiame darbe $<\ldots>$.

Gilios padèkos žodžiai tartini ponui universiteto rektoriui, profesoriams ir dr. Natkevičiui, kurie plačiai dalyvavo mokymo darbe Generalinio štabo kursuose, 
dar labiau sustiprindami ryši tarp kariuomenès ir universiteto, kas ypač reikšminga šiais laikais, kada mokslas labai plačiai prisideda prie kariuomenès ir krašto gynimo tobulinimo ir stiprinimo.

Ypatingai sunkų darbą teko atlikti šių kursų lektoriams. Kiekviena pradžia sunki, juo labiau šiuose kursuose, kur kiekvieną dalyką lektoriams tenka iš naujo rengti ir vykdyti, nes karybos srityje beveik nèra tokių pastovių doktrinų kaip matematika, kuri tinka visoms tautoms ir visoms valstybėms. Karo mokslo pagrindiniai nuostatai yra priimti tie patys visose kariuomenėse, bet jų pritaikymas kiekvienoje kariuomenejje savotiškas, skirtingas; jis pareina nuo tautos būdo, vietovės, ginklavimo, technikinio kariuomenès aprūpinimo ir daug kitų veiksnių.

Kiekviena karo akademija - savotiška laboratorija, kuri išskiria visa tai, kas savo kariuomenei tinka, ir nustato, kaip įvairias karybos mokslo sritis reikia taikyti gyvenime. Tokios rūšies platus darbas buvo atliktas ir mūsų Generalinio štabo kursuose; prireikè iš lektorių daug kūrybos ir labai jègas įtempti bei pasiaukoti <..."“. Visų Generalinio štabo kursų klausytojų vardu kalbejo gen. št. plk. V. Giedrys (Kardas, 1934, Nr. 11 (188), p. 203-204, 218-219).

Generalinio štabo kursų kelių metų patirtis parodè, kad kursus baigę karininkai buvo visiškai gerai pasirengę; ne vienas karininkas, baigęs kursų pirmają laidą, ịvairiuose kariuomenès štabuose, rikiuotès daliniuose ar karo mokslo srityje užèmė aukštas, atsakingas pareigas.

Lietuvos kariuomenès Vyriausiojo štabo viršininko (kartu ejjo ir kariuomenès vado pareigas) ir Generalinio štabo kursų viršininko pareigas gen. 1tn. P. Kubiliūnas ejjo iki $1934 \mathrm{~m}$. birželio $7 \mathrm{~d}$. Tais metais jis teistas už dalyvavimą birželio 7-8 d. voldemarininkų puče. 1936 m. įsakymu kariuomenei Nr. 74 (str. 5) naujuoju kursų viršininku skiriamas Gen. štabo plk. V. Karvelis, kursų inspektoriai: Gen. štabo plk. V. Kiršinas, intendantūros plk. K. Ramanauskas (neetatinis). 1932 m. įsakymai kariuomenei Nr. 20 (str. 2 ir 3), 1934 m. Nr. 67 (str. 6 ir 7) ir Nr. 75 (str. 2) panaikinami (LCVA, f. 384, ap. 1, b. 111, 1. 79, b. 123, 1. 121, b. 127, 1. 8).

Vyriausiojo štabo viršininkas gen. 1tn. P. Kubiliūnas ir Generalinio štabo valdybos viršininkas gen. 1tn. Z. Gerulaitis $1932 \mathrm{~m}$. lapkričio 16 d. paskelbtame Vyriausiojo štabo aplinkraštyje Nr. 25 teigia, kad 1934 m. rugsejjo mèn. prie Vytauto Didžiojo karininkų kursų numatoma organizuoti Generalinio štabo kursų II laidą (LCVA, f. 1451, ap. 1, b. 90, 1. 8).

Toliau tęsèsi Aukštujų karininkų kursų pertvarka ir jų likvidavimas. Antai 1933 m. birželio 1 d. krašto apsaugos ministras plk. B. Giedraitis ir Vyriausiojo štabo viršininkas gen. ltn. P. Kubiliūnas pasirašè įsakymą kariuomenei Nr. 39, kuriame teigiama, kad Vytauto Didžiojo karininkų kursai ūkio atžvilgiu priskiriami prie Pirmojo Lietuvos Prezidento karo mokyklos.

Vytauto Didžiojo karininkų kursų ūkio bylas ir turtą turèjo perduoti Pirmojo Lietuvos Prezidento karo mokyklai, išskyrus kursų Technikos skyriaus naudojamą turtą ir patalpas, kurias reikejjo perduoti karo technikos viršininkui.

Generalinio štabo kursus ūkio atžvilgiu aprūpina Vyriausiojo štabo ūkio sky- 
rius. Ši pertvarkymą reikejjo įvykdyti iki 1933 m. rugpjūčio 1 d. 1932 m. ịsakymas kariuomenei Nr. 20 nustojo veikęs.

1933 m. rugsejjo 6 d. ịsakymu kariuomenei Nr. 62 issakymas kariuomenei Nr. 39 papildomas taip:

Vytauto Didžiojo karininkų kursų skyriai nuo 1933 m. rugpjūčio 1 d. priklauso: a) Bendrasis ir Artilerijos skyriai visai atžvilgiais - Pirmojo Lietuvos Prezidento karo mokyklos viršininkui; b) Inžinerijos ir Technikos skyriai visais atžvilgiais karo technikos viršininkui; c) Administracijos kursų skyrius mokymo atžvilgiu tiekimų viršininkui, visais kitais atžvilgiais - Pirmojo Lietuvos Prezidento karo mokyklos viršininkui. Todèl iš dalies keičiamas 1933 m. įsakymo kariuomenei Nr. 3 str. 9 (LCVA, f. 384, ap. 1, b. 108, 1. 9, 75).

Galutiniam Vytauto didžiojo karininkų kursų ūkio ir administracijos (rikiuotès) bylų likvidavimui prižiūrèti skiriamas plk. P. Bytautas su teise pasirašinèti už kursų viršininką reikalingus raštus. Likvidavimą pravesti, laikantis 1933 m. ịsakymų kariuomenei Nr. 39 (str. 1), Nr. 62 (str. 1) ir slaptu įsakymu kariuomenei Nr. 5 nurodytos tvarkos (LCVA, f. 384, ap. 1, b. 108, 1. 84).

1934 m. liepos 24 d. įsakymu kariuomenei Nr. 67 Vytauto Didžiojo karininkų kursų Bendrojo skyriaus inspektorius buvo kartu ir Generalinio štabo kursu (neetatinis) inspektorius. Generalinio štabo kursų inspektorius tiesiogiai pavaldus Vyriausiojo štabo viršininkui (6 str.).

Generalinio štabo kursų tvarkymo reikalais visus nurodymus, remiantis 1932 m. ịsakymu kariuomenei Nr. 20 (3str.), Vyriausiojo štabo viršininkas duoda Generalinio štabo kursų inspektoriui (7 str.) (LCVA, f. 384, ap. 1, b. 111, 1. 111).

$1933 \mathrm{~m}$. vasario $20 \mathrm{~d}$. Vyriausiojo štabo aplinkraštyje Nr. 4 skelbiama, kad prie konkursinių egzaminų ị Generalinio štabo kursų II laidą prileisti 23 karininkai.

1934 m. sausio 8 d. įsakyme kariuomenei Nr. 8 teigiama, kad 15 karininku kandidatų (majorai - K. Dabulevičius, I. Kraunaitis; kapitonai - T. Kukta, A. Dapkus, S. Žukaitis, J. Juknevičius, A. Malijonis, V. Sutkus, K. Kėželis, N. Ferensas, J. Strikas, V. Bulvičius; leitenantai - S. Garalis, M. Gecevičius, R. Kiaulènas) priimta į Generalinio štabo kursų antrą laidą, nuo $1934 \mathrm{~m}$. sausio $8 \mathrm{~d}$. jie komandiruojami ị Vyriausiaji štabą ir toliau siunčiami ị ịvairias kariuomenès dalis stažuotei atlikti (LCVA, f. 384, ap. 1, b. 111, 1. 9).

$1935 \mathrm{~m}$. vasario $15 \mathrm{~d}$. kariuomenès aplinkraštyje Nr. 7 skelbiama, kad iš visu 1933 ir 1935 m. (Vyriausiojo štabo aplinkraščiai 1933 m. Nr. 14 ir 1934 m. Nr. 41) laikiusiujų ị Generalinio štabo kursų antrą laidą egzaminus, galutinai priimta klausytojais 21 karininkas (LCVA, f. 929, ap. 6, b. 169, 1. 67).

Generalinio štabo kursų antrosios laidos mokslo pradžia turejjo prasidèti 1934 m. rudeni, tačiau dèl tam tikrų priežasčių kursų antrosios laidos atidarymas ịvyko tik $1935 \mathrm{~m}$. kovo $1 \mathrm{~d}$. Bene svarbiausia iš tų priežasčių buvo ta, kad, pradejjus vykdyti tam tikrus organizacinius kariuomenès pertvarkymo darbus, pasirodé, kad anksčiau numatytų ir jau parengtų kandidatų į Generalinio štabo kursų antrą laidą yra per mažai, kad jų skaičių reikia padidinti bent dvigubai. Tam reikejo numatyti ir 
naujus kandidatus, duoti jiems laiko pasiruošti stojamiesiems egzaminams. Tačiau kursai ir programa buvo taip sutvarkyta, kad pavèlavimas nè kiek netrukdè mokslo eigai. Siekiant neatsilikti nuo Europos valstybių karybos mokslo ir pasisemti patirties, kurią būtų galima pritaikyti Lietuvos sąlygoms, iš naujai priimtų 23 klausytojų į Generalinio štabo kursų antrąją laidą po vieną karininką buvo išsiųsta ị Paryžiaus (mjr. I. Kraunaitis), Briuselio (mjr. P. Meškauskas) ir Prahos (mjr. V. Jankauskas) karo akademijas (Kardas, 1935, Nr. 10 (215), p. 222; Kardas, 1935, Nr. 24 (229), p. 549-551).

1934 m. rugpjūčio 10 d. įsakyme kariuomenei Nr. 75 (2 str.) teigiama, kad prie Vytauto Didžiojo karininkų kursų steigiami Intendantų kursai, kurių neetatiniu inspektoriumi skiriamas intendantas plk. ltn. K. Ramanauskas. Intendantų kursų inspektorius betarpiškai pavaldus Vyriausiojo štabo viršininkui. Intendantų kursus ūkio atžvilgiu aprūpina Vyriausiojo štabo ūkio skyrius (LCVA, f. 384, ap. 1, b. 111, 1. 120).

Kartu su Generalinio štabo kursų antros laidos iškilmingu mokslo metų pradžios atidarymu buvo pažymèta ir Intendantų kursų mokslo pradžia, nes jie mokslo metus pradèjo $1934 \mathrm{~m}$. rugsèjo $20 \mathrm{~d}$., norèta, kad Intendantu skyriaus klausytojai visuomenès ir valstybės ūkio bei teisès mokslus studijuotų Vytauto Didžiojo universitete, todèl teko derintis prie šios mokymo įstaigos mokslo metų pradžios.

Reikia pažymèti, kad iki tol reikalingi Lietuvos kariuomenei intendantai buvo ruošiami atitinkamose užsienio aukštosiose mokyklose. Tačiau dèl lěšų stokos šiam reikalui didesnį diplomuotų intendantų skaičių užsienio šalyse sunku buvo parengti. Todèl, įsteigus Vytauto Didžiojo karininkų kursų Generalinio štabo skyrių, kilo sumanymas pradèti rengti Lietuvoje ir diplomuotų intendantų specialybės karininkus.

Mokslo metų pradžios iškilmėse dalyvavo Respublikos Prezidentas A. Smetona, krašto apsaugos ministras gen. 1tn. P. Šniukšta, susisiekimo ministras J. Stanišauskas, Vytauto Didžiojo universiteto rektorius prof. M. Romeris, kariuomenès vadas Gen. štabo plk. S. Raštikis, Kariuomenès štabo viršininkas plk. J. Černius, aukštieji karininkai, kviestiniai svečiai ir patys klausytojai.

Vytauto Didžiojo universiteto rektorius prof. M. Romeris kalbejjo: „Man, kaip universiteto rektoriui ir tuo pat ex officio Lietuvos mokslo atstovui, šios dienos aktas yra malonus ir reikšmingas dvejopai - pirma, todèl, kad jis skiriamas Lietuvos laisvės išsaugojimo pajègoms racionalizuoti ir stiprinti ir tatai drauge ir kitoms Lietuvos pajègoms, neišskiriant ir mano atstovaujamo mokslo, svarbu, nes Lietuvos mokslas laisvai klesteti gali tik laisvoje Lietuvoje. Antra, todèl, kad drauge skiriamas ir mokslui, kurio racionalizacija yra ši krašto apsaugos funkcija. Be to, aš pats dalyvavęs pirmosios šių kursų laidos mokslo paruošimo darbe, kad ir neužimdamas specialès kursų srities, ịvertindamas jų atliktą darbą, džiaugiuos, kad šis darbas šioje srityje bus tęsiamas toliau ir duos Lietuvai gausingesnių vaisių.

Man malonu pasveikinti gerbiamają kursų vadovybę universiteto vadovybės vardu ir tiek gerbiamai kursu vadovybei ir visam jos mokomam personalui, tiek 
gerbiamiesiems kursantams pareikšti V. D. universiteto pagarbą ir širdingą, draugišką simpatiją.“

Kariuomenès vadas Gen. štabo plk. S. Raštikis kalbejjo: „Džiugu mums, kariams, kad mūsų kariuomenè savo eilèse susilaukè jau dviejų aukštujų karininkų mokyklų: Generalinio štabo kursų ir Intendantų kursų. Šitos mūsų mokyklos, teisybè, neturi skambių akademijų pavadinimų, bet esmé juk yra ne pavadinime, ne žodyje, bet susitvarkyme ir darbe. Generalinio štabo kursai jau turi pas mus praktiką ir ši kelių metų praktika parodè, kad iš tų kursų išèję karininkai yra visiškai gerai pasirengę. Juk ne vienas iš karininkų, baigusių Generalinio štabo kursų pirmają laidą, užima dabar aukštas, atsakingas vietas ir tai ịvairiuose kariuomenės štabuose, rikiuotès eilèse ar karo mokslo srityje. Ir šie žmonès, mūsų lietuviškuosius kursus baigę, kaip tik tvarkosi visiškai lygiomis su tais iš mūsų Generalinio štabo kolegų, kurie yra aukštuosius karo mokslus baigę garsiose Vakarų Europos kariuomenių akademijose.

Ir toliau, tobulindami savo Generalinio štabo kursus, be abejo, susilauksime visiškai rimtos ir geros mūsų aukštosios karo mokyklos. Tik mūsų Aukštieji intendantų kursai praktikos dar neturi. Bet reikia tikètis, o aš esu ịsitikinęs, kad, ir šioje srityje padeję daug darbo ir noro, susitvarkysime taip, kaip norėsime. Tad ir šie kursai, be abejonès, turès pasisekti ir pasiseks.

Generalinio štabo II laidos mokslo pradžia normališku laiku turèjo prasidèti pereitujų metų rudenį. Bet buvo priežasčių, kurių dẻlei ši mokslo pradžia buvo atidèta iki šių metų kovo $1 \mathrm{~d}$. Bene svarbiausia iš šių priežasčių buvo toji, kad, pradejus vykdyti tam tikrus organizacinius mūsų kariuomenès pertvarkymo darbus, pasirodè, jog anksčiau numatytų ir jau parengtų kandidatų ị Generalinio štabo kursų II laidą yra per maža, kad jujų skaičių reikia didinti, žymiai didinti, bent dvigubai. $\mathrm{O}$ jei reikia didinti skaičius, tai reikia numatyti ir naujuosius kandidatus, duoti jiems bent kiek laiko prie egzaminų pasirengti, sutvarkyti konkursą ir išegzaminuoti. Tam visam pirmiausia reikalingas laikas. Štai viena iš svarbiausių priežasčių, kodèl kursų pradžia buvo nustatyta ne rudenị, bet kovo mènesị. Tačiau kursai ir programa taip sutvarkyta, kad tas pavėlavimas nė kiek nekliudys mokslo eigai.

Apie Generalinio štabo kursų reikšmę man visiškai netenka kalbèti. Jo Ekscelencija Ponas Respublikos Prezidentas jau daug gilių minčiu mums čia pasakè. Be to, ir anksčiau šitais klausimai mūsų yra girdèta, skaityta ir rašyta. Aš čia norejjau tiktai viena pridèti, kad mes, pradejję rengti pas save Lietuvoje Generalinio štabo diplomuotus karininkus ir tuo būdu pereję prie vienodo diplomuoto karininko parengimo, negalime visiškai atsisakyti, atsiriboti nuo užsienio generalinio štabo akademijų. Mums ne vis tiek, kas tose akademijose dabar daroma, kokios naujos problemos sprendžiamos, kokie nauji metodai nagrinejami ir kokios naujos taktiškos bei strategiškos pažiūros ten gvildenamos. Tai svarbu žinoti, kad kitų patyrimas galima būtų pritaikinti ir savo lietuviškose sąlygose. Šitam viskam gauti informacijų vien tik iš spaudos nepakanka, tam reikalingi žmonès, kurie patys visa tai pergyventų ir pamatytų. Todèl reikalinga siųsti ir mūsų atstovai ị tas mokyklas. 
Todèl ir tarp naujai priimtų ị Generalinio štabo kursus karininkų bus numatyti keli, kurie jau šiais metais, ateinančią vasarą ar rudenį, turès išvykti ị Vakarų Europos generalinio štabo kursus, bent po vieną ị Paryžiaus, Briuselio ir Prahos mokyklas. Generalinio štabo kursų lektoriams taip pat gal teks trumpesnị laiką išvykti ị vieną kitą Vakarų Europos akademiją savo žinioms pagilinti ir vietoje prisižiūrèti <...>." (Kardas, 1935, Nr. 6 (211), p. 120-122).

Mokymo laikas paskirstytas ị parengiamaji (stažuotès), pirmuosius ir antruosius mokslo metus. Stažuote atlikta ịvairiuose ginklų rūšių daliniuose, poligone ir Kariuomenès štabe ir trūko 14,5 mėnesio, o akademinis mokslas -2 metus ir 4 mènesius. Kiekvieni mokslo metai buvo suskirstyti ị tris trimestrus po 3-4 mėnesius, o paskutinis truko net 6 ménesius. Kiekviename trimestre studijuotas tam tikras teorijos ir ịvairių pratybų ciklas. Kiekvienas trimestras baigèsi arba pratybomis lauke, arba karo žaidimu arba taktine kelione. Paskutinis trimestras buvo baigtas karo žaidimu, baigiamaisiais darbais ir taktine bei istorine kelione.

Kasdien auditorijose buvo mokomasi 5-6 val., o pratybos lauke, kurių buvo daug, užtrukdavo nuo ryto iki sutemų, t. y. 10-12 val., o kartais ir daugiau. Po pietų ir vakarais, o kartais ir dar vèlesniu laiku klausytojai turèjo rengti parengiamuosius darbus kitai dienai.

Generalinio štabo antrosios laidos klausytojai buvo mokomi pagal analogišką pirmosios laidos mokymo programą. Kursuose mokymo pagrindu irgi taikomas eksperimentinis metodas. Nauja šioje laidoje tai, kad ịvedamos instruktavimo pratybos, kuriu tikslas - klausytoją parengti taktikos mokymo vadovo instruktoriaus pareigoms (Kardas, 1935, Nr. 24(229), p. 549-551; Mūsų žinynas, 1937, t. 33, Nr. 7 (148), p. 85-86).

Darbui auditorijoje (paskaitoms, pratyboms ir t. t.) buvo skirta apie 500 dienu (arba apie 2500 val.), o darbui lauke (pratybos ir taktinès kelionès) - per 100 dienu (arba per 1000 val.). Santykis tarp auditorinių valandų ir skirtų darbui lauke valandų $-2,5: 1$. I ši valandų skaičiu neįèjo klausytojų pasirengimas namie. Be paskaitų, karo žaidimų ir taktinių kelionių vien tik eksperimentinių pratybų iš visų mokslo dalykų per du mokslo metus klaseje atlikta apie 200, lauke - apie 60 (Kardas, 1937, Nr. 13 (267), p. 303-306).

Naujai ịsteigto Intendantu skyriaus tikslas - parengti išsilavinusius intendantų specialybės karininkus. Baigę ši skyrių, karininkai turèjo sugebėti eiti stambesnių kariuomenès junginių (divizijų) intendantų pareigas, o taip pat vadovauti kariuomenès Intendantūros centro įstaigų darbui. Šio skyriaus mokymo programa bendrais bruožais atitiko užsienio valstybių tokio tipo mokyklų programas. I pirmają Intendantų skyriaus laidą buvo priimti tik 8 klausytojai, nes, išleidus didesni diplomuotų intendantų skaičių, susidarytų kai kuriu problemų, skirstant juos į negausias intendantūros tarnybas. Kadangi nuo sumanymo steigti intendantų skyrių iki numatomo jo mokslo pradžios buvo likę labai nedaug laiko, tai klausytojai ị pirmąją laidą priimami ne konkurso būdu, bet vadovybès parinkti iš karininkų tarpo, kurie pareiškè pageidavimą studijuoti kursuose. 
Dèl lèšų taupymo mokslo eiga šiame skyriuje susidarè gana sudètinga, nes klausytojai programoje numatytus dalykus turejjo studijuoti trijose mokymo įstaigose: Vytauto Didžiojo generalinio štabo skyriuje, intendantų skyriuje ir Vytauto Didžiojo universitete. Klausytojams leista užsienio kalbas mokytis Generalinio štabo kursų skyriuje arba universitete.

Intendantų skyriaus mokslas prasidèjo $1934 \mathrm{~m}$. rugsèjo $20 \mathrm{~d}$. ir baigèsi 1937 m. birželio 28 d. Visą mokymosi laiką galima suskirstyti ị tris etapus. Pirmojo etapo (1934 m. rugsejjo $20 \mathrm{~d}$. $-1935 \mathrm{~m}$. kovo $1 \mathrm{~d}$.) metu mokslas vyko Vytauto Didžiojo universitete; antrojo etapo (1935 m. kovo 1 d. - 1936 m. gruodžio 31 d.) Generalinio štabo skyriuje, Intendantu skyriuje ir Vytauto Didžiojo universitete; trečiojo etapo (1937 m. sausio $1 \mathrm{~d}$. $-1937 \mathrm{~m}$. birželio $28 \mathrm{~d}$.) - Generalinio štabo skyriuje ir Vytauto Didžiojo universitete. Visas mokslas tęsèsi 2 metus ir 9 mènesius (Kardas, 1937, Nr. 13 (267), p. 309-310).

Intendantų skyriaus klausytojai Generalinio štabo skyriuje kartu su šio skyriaus klausytojais išklausė gana didelę dalį bendrosios taktikos teorinių paskaitų ir atliko nemažai eksperimentinių bendrosios taktikos pratybų, kurios sudare Generalinio štabo ir intendantūros lauko tarnybos eksperimentinių pratybų pagrindą; išstudijavo visą Generalinio štabo tarnybos kursą, o iš ginklų rūšių taktikos (pėstininkų, kavalerijos ir artilerijos) dalyvavo tik keliose charakteringesnèse pratybose, kuriu metu turèjo paaiškèti tų ginklų rūšiu kautynèse panaudojimo ypatybės, kurios turi įtakos jų aprūpinimui. Be to, Intendantūros skyriaus klausytojai dalyvavo visuose karo žaidimuose ir abejose taktinèse kelionėse. Karo žaidimų ir taktinių kelionių metu jiems teko padirbèti įvairių kariuomenès junginių intendantų ir kitų ūkio pareigūnų pareigose. Šiame skyriuje jie taip pat išklausè mobilizacijos, tarptautinès teisès paskaitas ir mokèsi užsienio kalbų.

Intendantų skyriuje tik intendantūros lauko tarnyba buvo dèstoma paskaitų ir eksperimentinių pratybų metodu, o kiti dalykai - teorinių paskaitų forma, tačiau, kur tik buvo galima, taikomas parodomasis metodas. Teorinèse paskaitose aptartieji dalykai praktinių darbų ir mokomujų ekskursijų metu buvo apžiūrimi ir detaliai nagrinejjami. Be to, studijuota taikos meto ūkis, techniškoji maitinimo tarnyba, dangos ir aprangos medžiagų bei reikmenų technologija ir gamyba, ūkio mobilizacija, techniškosios intendantūros tarnybos instaliacijos, arkliai ir jų priežiūra, karo baudžiamoji teisè, statyba, vykdoma praktika įmonèse, mokomasi užsienio kalbų ir jojimo (Kardas, 1937, Nr. 13 (267), p. 305-306).

Vytauto Didžiojo universitete kartu su studentais studijuota politinė ekonomija, statistika, ūkio geografija, prekių, finansų mokslas, valstybinè, civilinė, administracinè, prekybinè teise, knygvedyba, socialinè apsauga, privataus ūkio mokslas. Intendantų skyriaus klausytojams, besitaikantiems prie universiteto tvarkos, paskaitu teko klausyti popiet. Be paskaitų ir praktikos įmonèse, darbo metodas buvo panašus ị Generalinio štabo skyriaus metodą. Mokslo metus užbaigè birželio 2-20 d. organizuota Generalinio štabo ir Intendantų skyriaus mokymo plane numatyta taktiné kelionè ị Vakarų Aukštaitijos ir Pietų Žemaitijos apylinkes, kuri suteikẻ klausy- 
tojams progą ịgytas žinias praktiškai pritaikyti tariamų kautynių lauke, išbandyti savo pasirengimo laipsni ir jègas: per pratybas, vykdant taktinius uždavinius lauke ir vadavietėse, padirbèti vadų ir štabų bei tarnybų pareigūnų pareigose; kautynių eigoje laiku susiorientuoti ir priimti pagal susidariusias aplinkybes sprendimus; pažinti ir ịvertinti didesnị savo krašto vietovès plotą (Kardas, 1937, Nr. 13 (267), p. 307-310).

Respublikos Prezidento 1936 m. lapkričio 23 d. aktu Nr. 1372 Vytauto Didžiojo karininkų kursų inspektorius Generalinio štabo plk. V. Karvelis atleidžiamas iš užimamų pareigų ( 2 str.) ir skiriamas kursų viršininko pareigas eiti (5 str.). Respublikos Prezidento 1936 m. lapkričio 23 d. aktu Nr. 1373 Kariuomenès štabo III skyriaus viršininkas Generalinio štabo plk. 1tn. V. Kiršinas atleidžiamas iš užimamu pareigų ir skiriamas kursų inspektoriumi (4 str.) (LCVA, f. 384, ap. 1, b. 123, 1. 121).

Gen. štabo plk. V. Kiršinas 1937 m. rašè, kad „Generalinio štabo ir Intendantų skyrių mokymo programos prilygsta, o kai kuriuose dalykuose net platesnès negu tolygiose užsienio karo mokslo įstaigose, kurios ten vadinamos aukštosiomis karo mokyklomis (Prancūzija, Čekoslovakija, Lenkija, Latvija, Estija) ar akademijomis (Rusija) ir turi aukštujų karo mokyklų teises. Tuo tarpu mūsų aukštoji karo mokykla vadinama kursais.

Kilo reikalas šị klausimą sutvarkyti ịstatymo keliu. Kariuomenès vadui ịsakius, tokio įstatymo projektas parengtas ir ịteiktas kariuomenès vadovybei.

Šiuo įstatymu Vytauto Didžiojo karininkų kursus siūloma vadinti Vytauto Didžiojo aukštaja karo mokykla. Mokyklai suteikiamos aukštosios karo mokyklos teisès. İstatymą turès papildyti atitinkamos karo vadovybès išleistos taisyklès ir mokyklos statutas, kuris jau baigiamas rengti.“

„<..> Panašus reikalas ir su Generalinio štabo bei Intendantų skyrių baigimo ženklu (aukštosios mokyklos). Šis klausimas laukia greito galutinio išsprendimo, nes š. m. balandžio mèn. $10 \mathrm{~d}$. konkurso keliu gaunami ženklų projektai. Norima, kad ženklas atitiktų šias sąlygas: išreikštų valstybinę emblemą, pažymėtų Vytauto Didžiojo asmenį, turètų laurų ar ąžuolo lapų vainiką, atitiktų mokslinę skyriaus paskirtị, būtų gražus ir praktiškas <...>." (Kardas, 1937, Nr. 13 (267), p. 307-308).

1937 m. birželio 28 d. įvyko Generalinio štabo kursų skyriaus antrosios laidos ir Intendantų pirmosios skyriaus laidos ịspūdingos išleistuvès.

Generalinio štabo skyriaus II laidą baige ir igijo Generalinio štabo karininko teises 20 karininkų: majorai - T. Bartkus, P. Bilevičius, K. Dabulevičius, P. Grèbliauskas, J. Juknevičius, M. Mačiokas, J. Šepetys, P. Žukas ir S. Žukaitis; kapitonai - V. Bulvičius, N. Ferensas, M. Gecevičius, J. Giedra, A. Impulevičius, R. Kiaulėnas, T. Kutka, A. Malijonis, M. Naujokas, J. Navikas ir V. Sutkus (LCVA, f. 384 , ap. 1, b. 127, 1. 55).

Intendantų skyriaus I laidą baigè ir igijo intendanto teises 7 karininkai: kapitonai - J. Bačkys, V. Baršauskas, J. Būbelis, V. Gogelis ir J. Liūga; leitenantai V. Černius ir J. Petraitis (Kardas, 1937, Nr. 13 (267), p. 311).

Mokslo metų pabaigos iškilmès pradètos Karo muziejaus sodelyje. 9.00 val. 
Vytauto Didžiojo karininkų kursų lektoriai ir klausytojai susirinko prie žuvusiųjų paminklo. Kursų viršininkas Gen. štabo plk. V. Karvelis ir abiejų skyrių vyresnieji Gen. štabo mjr. M. Mačiokas ir int. kpt. V. Baršauskas, grojant orkestrui gedulingą maršą, padejo vainiką prie Nežinomo kareivio kapo.

Po pamaldų Kauno igulos bažnyčioje Lietuvos karininkų ramovės didžiojoje salejje ịvyko iškilmingos išleistuvès, kuriose dalyvavo Respublikos Prezidentas A. Smetona, Ministras Pirmininkas J. Tūbelis, Seimo Pirmininkas K. Šakenis, krašto apsaugos ministras brg. gen. S. Dirmantas, užsienio reikalų ministras S. Lozoraitis, vidaus reikalų ministras ats. brg. gen. J. Čaplikas, kariuomenès vadas Gen. štabo plk. S. Raštikis, gen. S. Žukauskas, 1. e. tiekimo viršininko pareigas brg. gen. K. Navakas, valstybès kontrolierius J. Mašiotas, Kauno miesto burmistras A. Merkys, brg. gen. E. Vimeris, brg. gen. K. Popeliučka, brg. gen. K. Tallat-Kelpša, aviacijos viršininkas plk. A. Gustaitis, Šaulių sajungos vadas plk. P. Saladžius, SSSR karo atašè plk. Tiagunovas, Latvijos karo atašè Gen. štabo kpt. Deglavas, Kauno igulos dalinių vadai, karo ịstaigų viršininkai ir spaudos atstovai.

Išleistuves pradèjo Vytauto Didžiojo karininkų kursų viršininkas Gen. štabo plk. P. Karvelis, o kursų inspektorius Gen. štabo plk. V. Kiršinas perskaite ịsakymą kariuomenei apie kursų baigimą. Respublikos Prezidentas A. Smetona klausytojams įteike diplomus, sveikindamas kiekvieną baigusijji rankos paspaudimu.

Po diplomų įteikimo Aukštụjų karininkų kursų viršininkas Gen. štabo plk. P. Karvelis savo pranešime plačiai nušviete kursų veiklą ir pamokančiu žodžiu kreipėsi ị baigusius mokslą klausytojus: „< ..> Nepamirškite, kad mūsų kariuomenei, turint galvoje mūsų sąlygas, kritišku ir sunkiu momentu teks pakelti daug sunkesnę naštą, negu kitų valstybių kariuomenèms. Todèl ir kiekvienam Jūsų teks dirbti daug daugiau, dažnai keliose pareigose, negu panašūs pareigūnai dirba kitoje kariuomeneje. Tai žinodami, pratinkitès ir grūdinkitès jau dabar, taikos metu <...>." (Kardas, 1937, Nr. 13 (267), p. 306).

Kariuomenès vadas Gen. štabo plk. S. Raštikis pabrèžè, kad baigę mokslus savo krašte karininkai savo pasirengimu visiškai prilygsta baigusiems mokslus užsienyje.

<..> Mūsų kariuomenei nereikalingi ,genštabistai“, teoriškai ir paviršutiniškai pasiruošę valdyti sudètingas armijas, o praktiškai nesugebą duoti aiškaus ir konkretaus uždavinio net paprastam pèstininkų batalionui; mums nereikalingi ,intendantai“ - akli, nepermaldaujami ir trukdą darbą biurokratai arba tik diplomuoti buhalteriai. Tokių mums nereikia. Mums visose ginklų rūšyse ir tarnybose reikalingi stipraus būdo, tvirtos valios, šaltų nervų, savarankiški, logiškai ir realistiškai galị galvoti ir spręsti ir sugebą nepaskęsti smulkmenose, darbštūs, kupini iniciatyvos ir optimizmo ir visa siela atsidavę Tèvynei ir tarnybai vadai ir viršininkai.

Tèvynès meilè, garbè ir pareiga turi būti kiekvieno, o ypatingai diplomuoto, karininko gyvenimo rodyklè.“ (Kardas, 1937, Nr. 13 (267), p. 302).

Respublikos Prezidentas A. Smetona, sveikindamas aukštąi karo mokslą baigusius karininkus, pažymėjo, kad „, $<>>$ mokyti kariai reikalingi Šaulių sajungai, 
kaip pagelbinei ginklo pajègai. Turime jaunimo organizacijų, kurioms tiktų kariniai auklètojai. Jaunuoliai mègsta kariuomenę ir ị ją lygiuojasi. Jaunuoliai - gera medžiaga tautai stiprinti.

Mūsų karininkų reikšmė labai didelė ir kitose valdymo srityse, ypačiai Vidaus reikalų ministerijoje, kur jie eina atsakingas pareigas. Ir savivaldybèse atsargos karininkai dažnai stovi priešakinèse vietose kaip miestų burmistrai. Žodžiu sakant, kariuomenè duoda labai daug žmonių krašto administracijai.

Vadinasi, mūsų paprastoji ir aukštoji karo mokyklos savo svoriu siekia toli už kariuomenès ribų ir dèl to kiekviena jų laida esti laimikis ne tik kariuomenei, bet ir visuomenei.“

Karo mokslas ,turi būti tautiškas, pritaikytas taip, kaip reikalauja ir leidžia mūsų ginklo pajègos. Mūsų aukštoji karo mokykla čia daug yra pasiekusi. Taigi, mes džiaugiamės ne vien tuo, kad mūsų mokytų karininkų padaugèjo, bet ir tuo, kad mūsų karo mokslas sustiprèjo. Reikia tikètis, kad toliau jis dar stiprès $<\ldots .>$." (Kardas, 1937, Nr. 13 (267), p. 301).

Visų baigusių kursus karininkų vardu pasisakè kursų vyresnysis Gen. štabo mjr. M. Mašiotas: „<..> Mus džiugina ir kelia mumyse pasididžiavimą, kad turèjome progos ịgyti aukštaji karo mokslą savojoje mokykloje savojo krašto sąlygomis, savo jègomis ir priemonèmis, kurių taip gausiai, atsižvelgiant ị mūsų valstybės išteklius, teikè mūsų vadovybè.

Prie šių sąlygų ịgytos žinios, tikime, bus mūsų kariuomenei naudingesnès, o mums jos brangesnès negu svetur gautos <... ." (Kardas, 1937, Nr. 13 (267), p. 311-312).

1935 m. lapkričio 30 d. kariuomenès aplinkraštis Nr. 22 skelbè, kad 40 karininkų leista laikyti konkursinius egzaminus ị Vytauto Didžiojo karininkų kursų Generalinio štabo skyriaus III laidą (LCVA, f. 929, ap. 6, b. 170, 1. 128). Konkursiniai egzaminai numatyti $1936 \mathrm{~m}$. spalio 5 d. Vytauto Didžiojo karininkų kursų patalpose. Egzaminai laikomi iš šių dalykų: bendroji taktika (raštu), geografija (raštu), lietuvių kalba (raštu), topografija (raštu), bendroji taktika (žodžiu), pèstininkų taktika (iš pėstininkų taktikos programos p. A), pėstininkų taktika (iš pėstininkų taktikos programos p. B), karo istorija (žodžiu), geografija (žodžiu), istorija (žodžiu), Rytu Europos kalbos (rusų, lenkų), Vakarų Europos kalbos (prancūzų, vokiečių) (LCVA, f. 929, ap. 6, b. 183, 1. 68). Konkursinius egzaminus ị Generalinio štabo kursų trečią laidą iš 34 laikiusiujjų išlaikè 24, tačiau 2 dèl konkurso ị kursus nepriimti (LCVA, f. 929 , ap. 6, b. 182, 1. 31).

Generalinio štabo kursų trečioji laida mokslo metus pradejjo 1937 m. rugsèjo 1 d. Šios laidos mokslo metų pradžia buvo pažymèta kukliai, be ypatingų ceremonijų. Konkursinius egzaminus išlaikius, ị mokyklą ịstodavo tik apie $25-30 \%$ kandidatų.

Trečioji laida mokslo metus pradejo laiku - kaip ir visos mokyklos. Šios laidos mokymo programa buvo panaši i a antrosios laidos, tačiau su kai kuriais pakeitimais, susijusiais su dviejų metų patyrimu. Šiai laidai kursas šiek tiek padidintas, 
o visas mokymo laikas keliais mènesiais sutrumpintas: numatyta daugiau karo žaidimų, pratybų lauke ne tik vasarą, bet ir žiemą ir t. t. Kursų viršininkas Gen. štabo plk. P. Karvelis pirmaja paskaita „Pagrindiniai sprendimo elementai“ pradejo akademines studijas trečiojoje laidoje (Kardas, 1939, Nr. 15 (317), p. 378-379).

Dar prieš išleidžiant trečiają laidą, buvo surinkti kandidatai laikyti konkursinius egzaminus ketvirtajai laidai. 1938 m. spalio 8 d. 39 karininkai atvyko ị kursus ir pradejo laikyti antruosius konkursinius stojamuosius egzaminus i Generalinio štabo skyriaus ketvirtają laidą (LCVA, f. 1451, ap. 1, b. 106, 1. 6).

\section{Vytauto Didžiojo aukštoji karo mokykla}

1938 m. spalio 11 d. svarstant Seime Vytauto Didžiojo aukštosios karo mokyklos įstatymo projektą, laikinai einantis krašto apsaugos ministro pareigas kariuomenès vadas brg. gen. S. Raštikis kalbèjo: „, <..> Savo aukštają mokyklą faktinai turime, tai - Aukštieji karininkų kursai, kurie veikia Vytauto Didžiojo vardu. Jie veikia 1922 m. priimtu statutu, kuris yra nutolęs nuo gyvenimo, kad dabar beveik neįmanoma jo vykdyti. Atskirais kariuomenès vadovybès įsakymais kursai kelis kartus pertvarkyti, jau yra išleidę kelias Generalinio štabo ir intendantūros specialybės karininkų laidas, jie veikia ir yra taip sutvarkyti, kaip nurodyta dabar Seime svarstomame įstatyme. Seimas dabar prašomas ne kokių naujumų ịvesti, bet įteisinti esamą padèti.

Nenoreta reklamuotis „Karo akademijos“ ar „Generalinio štabo akademijos“ vardu, parinktas kuklesnis ir tikrai lietuviškas pavadinimas - Aukštoji karo mokykla. Turime Karo mokyklą, turèsime ir Aukštają karo mokyklą. Suteikti tai mokyklai aukštosios mokyklos vardą ir teises reikia, nes karininkui šią mokyklą baigti reikia ne tik pasiruošimo, darbo, bet ir laiko studijoms ne mažiau nei studentui universitete ar kitoje aukštojoje mokykloje. Juk dabar ị Karo mokyklą priimami tik baigę gimnaziją. Karo mokykloje turi mokytis trejus metus. Po to tik geriausieji karininkai, atlikę stažą, pasiruošę ir išlaikę dvejus konkursinius egzaminus, gali patekti ị Aukštają karo mokyklą, kur mokslas su ginklų rūšių praktika trunka taip pat trejus metus, o gali būti ir ketverius. Tik po to karininkas gali gauti diplomuoto karininko vardą. Taigi, atrodo, kad diplomui gauti iš karininko net daugiau reikalaujam nei iš studento kitose civilinèse aukštosiose mokyklose.“

Kariuomenès vadas brg. gen. S. Raštikis nurodè, „<...> kad dabar mokosi trečioji Generalinio štabo skyriaus karininkų laida ir ruošiami kandidatai ketvirtajai laidai, o Intendantų skyrius tèra išleidęs tik vieną laidą ir tuo tarpu naujos laidos neturi, bet prireikus ji galès būti sušaukta. Kitu skyrių taip pat neturi, bet reikia kariuomenès vadovybei palikti laisvę pačiai spręsti, jei kils reikalas, kad ji ateityje galètų ir kitus skyrius, pvz., artilerijos, kavalerijos, aviacijos, karo technikos ir kt. ịsteigti. Visų dèstomų dalykų įstatyme pažymèti negalima, nes tai būtų negyvenimiška. Karo mokslas negali būti sustingęs, jis nuolat taikosi prie naujų gyvenimo aplinkybių. Kas šiandien aktualu, tas rytoj gali būti visai nesvarbu ir antraip, užtat 
šioje srityje įstatymas numato didesnị lankstumą ir paveda šį reikalą tvarkyti kariuomenès vadui. Mokslo personalas pavadintas ne profesoriais, bet lektoriais, nes personalo daugumą sudaro tikrosios tarnybos karininkai, kurie negali dirbti vienos srities tyrinejjimuose ir mokslo studijose, nes, visų pirma, jie yra vadai ir jų visa tarnybos eiga turi būti tvarkoma ne kaip mokslo žmonių, bet kaip karininkų - vadų. I mokyklą priimami tik ligi kapitono laipsnio ir ne senesni kaip 35 m. amžiaus dèl to, kad per eilę metų nuolat tobulinant karininkų kadrą ir renkant kandidatus i ịvairias mokyklas ir kursus, buvo taip perkošti visi karininkai, kad jau atèjo laikas, jog vyresnieji jau užima atsakingas vietas arba jau yra baigę ịvairias mokyklas ir kursus arba jie pasiekę tokị amžių ir užimamą vietą, kad dèl ịvairių priežasčių jau neapsimoka jų sodinti ị vieną suolą su leitenantais ir versti čia mokytis trejus ar ketverius metus, kad po to galètų užimti beveik tas pačias vietas, kurias jie dabar yra užèmę. Kitas reikalas tuos karininkus tobulinti ịvairiuose trumpesniuose kursuose, nors ir prie tos pačios Aukštosios mokyklos. Toks tobulinimas yra ir bus daromas. I Aukštają mokyklą atsiranda gana daug kandidatų. Pvz., ị naują karininkų laidą, kuri susirinks tik 1939 m. rudenị, jau dabar yra raštu pareiškę norą ịstoti 96 karininkai, o priimti galima tik apie 25 karininkus.“

Baigdamas pranešimą, brg. gen. S. Raštikis pareiškè, , <...> kad šị įstatymą prièmus, nereikès naujų išlaidų daryti, nes bus tik ịteisinta tai, kas ligi šiol jau vykdoma“" (Karys, 1938, Nr. 41 (1009), p. 1143-1144).

1 lenteleje pateikti duomenys rodo, kad Generalinio štabo kursuose daugiausia mokèsi pėstininkų specialybès karininkai.

1 lentelè. Generalinio štabo kursų klausytojai pagal specialybes (\%)

\begin{tabular}{|l|c|c|c|c|c|}
\hline \multirow{2}{*}{ Specialybės } & \multicolumn{4}{|c|}{ Generalinio štabo kursų laidos } & \multirow{2}{*}{ Vidutiniškai } \\
\cline { 2 - 5 } & I laida & II laida & III laida & IV laida & \\
\hline Pėstininkai & $\mathbf{5 0}$ & $\mathbf{4 6}$ & $\mathbf{7 5}$ & $\mathbf{6 6 , 5}$ & $\mathbf{5 9 , 3 7}$ \\
Artilerija & $\mathbf{1 9}$ & $\mathbf{1 6 , 5}$ & $\mathbf{2 0}$ & $\mathbf{8 , 5}$ & $\mathbf{1 6}$ \\
Kavalerija & - & $\mathbf{8 , 5}$ & $\mathbf{5}$ & $\mathbf{1 6 , 5}$ & $\mathbf{7 , 5}$ \\
Aviacija & - & $\mathbf{1 2 , 5}$ & - & $\mathbf{4 , 2 5}$ & $\mathbf{4 , 1 9}$ \\
Inžinerija & $\mathbf{3 1}$ & $\mathbf{1 6 , 5}$ & - & $\mathbf{4 , 2 5}$ & $\mathbf{1 2 , 9 4}$ \\
\hline
\end{tabular}

1938 m. gruodžio 10 d. Respublikos Prezidentas A. Smetona paskelbẻ Seimo priimtą (1938 m. gruodžio 1 d.) įstatymą, pagal kurị Vytauto Didžiojo karininkų kursai pavadinami Vytauto Didžiojo aukštaja karo mokykla, kurios tikslas - 1) suteikti karininkams aukštojo karo mokslo žinių, 2) kurti ir tobulinti karo mokslą ir jo rezultatus taikyti krašto sąlygoms ir poreikiams (1, 2 str.).

3 str. minimas Intendantų skyrius veikè tik su antra Generalinio štabo skyriaus laida. Kitų skyrių įkurti nespejo.

Aukštojoje karo mokykloje dėstoma bendroji, ginklų rūšių ir tarnybų taktika, karo istorija, karo geografija. 4 str. 4 punkte minimi papildomi kariniai dalykai - tai 
paskaitos, kurių metu klausytojai buvo supažindinami su karine žvalgyba ir kontržvalgyba, užsienio valstybių karo laivynais ir pan. Minimi bendrieji mokslo dalykai - valstybinè ir tarptautinè teisè, karo psichologija, lietuvių, užsienio kalbos ir kūno kultūra. Mokslo planą nustato kariuomenès vadas.

Pedagogini personalą sudaro etatiniai ir neetatiniai lektoriai. Pedagogini personalą parenka kariuomenès vadas (5-6 str.). Lektoriais gali būti: 1) kariniams dalykams - karininkai, baigę aukštają karo mokyklą, 2) bendriesiems ir kitų specialybių dalykams - karininkai, igiję aukštaji ar aukštajị bendrajj išsilavinimą, arba su aukštuoju išsilavinimu civiliai asmenys, 3) papildomiems specialiems karo dalykams, užsienio kalbos ir fiziniam lavinimui - atitinkami specialistai, nors ir neturintys aukštojo išsilavinimo (7 str.). Mokyklai vadovauja viršininkas, kuris pavaldus kariuomenès vadui (8 str.).

Lektorių tarybą sudaro mokyklos viršininkas, inspektorius ir aukštają karo mokyklą baigę lektoriai. Prireikus mokyklos viršininkas ị lektorių tarybos posèdžius gali kviesti ir kitus mokyklos lektorius patariamuoju balsu (9 str.). Lektorių tarybą kviečia ir jai vadovauja mokyklos viršininkas (10 str.). Lektorių taryba: 1) svarsto mokslo ir mokymo klausimus, 2) vertina klausytojų pažangumą (11 str.).

Klausytojų skaičių, mokslo pradžią ir pabaigą nustato kariuomenès vadas (12 str.). Klausytojais galëjo būti: 1) tikrosios karo tarnybos karininkai ne aukštesni nei kapitono laipsnio, 2) ne vyresni kaip $35 \mathrm{~m}$. amžiaus, 3) ištarnavę karininkais ne mažiau kaip $5 \mathrm{~m}$., taip pat ne mažiau kaip $3 \mathrm{~m}$. rikiuotèje, 4) per paskutinius dvejus metus gerai atestuoti, 5) sveikatos atžvilgiu tinkami rikiuotei, 6) išlaikę kariuomenès vado nustatytus konkursinius egzaminus (13 str.). I mokyklą klausytojus skiria kariuomenès vadas pagal mokyklos viršininko pateiktą išlaikiusiųjų konkursinius egzaminus karininkų sąrašą (14 str.).

Akademinio mokslo trukmè (15 str.) - dveji metai. Kariuomenès vadas (16 str.) galejjo akademinio mokslo laiką pratęsti iki 6 mènesių. Klausytojai atlieka vienerių metų stažuotę kariuomenès daliniuose. Kariuomenès vadas stažuotę dalyse gali prailginti, sutrumpinti ar visai neskirti (16 str.).

Norint baigti mokyklą, reikia: 1) įsisavinti mokyklos programą, 2) atlikti mokymo plane numatytus baigiamuosius darbus arba išlaikyti nustatytus egzaminus, 3) turèti gerą atestaciją (17 str.). Karininkas, atitinkantis nustatytas 17 str. sąlygas, gauna mokyklos baigimo diplomą, kuris suteikia aukštojo karo mokslo baigimo teisę. Diplomą pasirašo kariuomenès vadas ir mokyklos viršininkas (18 str.). Klausytojas mokymo metu iš mokyklos gali būti atleistas kariuomenès vado įsakymu: 1) jo paties prašymu, 2) dèl netinkamo elgesio, 3) dèl ligos, 4) dèl nepažangumo (19 str.).

Už kiekvieną Vytauto Didžiojo aukštojoje karo mokykloje išbūtą mėnesi karininkas turèjo atitarnauti kariuomenèje tris mènesius. Jeigu karininkas už mokymosi laikotarpi negalëjo atitarnauti, turẻjo grąžinti už mokslą išlaidas ar jų dalị valstybei, priklausomai nuo to, kiek laiko jis dar bus neatitarnavęs (20 str.).

Karininkai, gavę diplomus, igyja: 1) dvejus metus vyresniškumo turimam ar artimiausiam laipsniui, 2) teisę nešioti mokyklos atitinkamo skyriaus baigimo žen- 
klą (21 str.). Klausytojams, išklausiusiems atitinkamo skyriaus kursą ir negavusiems diplomų, po dviejų metų galèjo būti pripažintos baigimo teisès, jeigu: 1) perlaiko neišlaikytų dalykų egzaminus, 2) patenkinamai atlieka kariuomenès vado nustatytą stažuotę ir specialų darbą, 3) per tuos dvejus metus būna gerai atestuoti (22 str.).

Be to, šiuo įstatymu sutvarkytos ir anksčiau baigusių Generalinio štabo skyriaus pirmają ir antrają laidas ir Intendantų skyriaus pirmają laidą karininkų teisès ir pareigos (20 ir 22 str.), nes 1922 m. Aukštųų karininkų kursų statute, pagal kurị iki tol veike ir Vytauto Didžiojo karininkų kursai, apie aukštojo karo mokslo baigimo teises visai nebuvo kalbama, o Intendantų skyrius jame nenumatytas, neturejo ir teisinio pagrindo.

Pareigos nurodytiems karininkams lieka tos pačios, kurios buvo nustatytos Krašto apsaugos ministerijos stipendiju ịstatymo pakeitime (Vyriausybės žinios, 1931 m. gegužès 16 d., Nr. 357, eil. Nr. 2426, p. 6).

Karininkams, baigusiems Aukštajai karo mokyklai tolygias karo mokyklas užsienyje, pristačius diplomą ir kariuomenès vadui ji patvirtinus, taikomos numatytos 21 str. 1 punkte jo teisès (25 str.).

Vytauto Didžiojo karininkų kursai šiuo ịstatymu tampa Vytauto Didžiojo aukštaja karo mokykla (26 str.). Šiam ịstatymui vykdyti krašto apsaugos ministras leidžia taisykles (27 str.). Aukštujų karininkų statutas (Vyriausybės žinios, 1922 m., Nr. 111, eil. Nr. 867) panaikinamas (28 str.). Šis ịstatymas įsigaliojo nuo jo paskelbimo dienos (29 str.) (Vyriausybės žinios, 1938 m. gruodžio 10 d., Nr. 627, eil. Nr. 4503, p. 557-558).

1938 m. gruodžio 17 d. buvo paskelbtas įsakymas kariuomenei Nr. 90 Vytauto Didžiojo karininkų kursus nuo 1938 m. gruodžio 10 d. vadinti Vytauto Didžiojo aukštaja karo mokykla (Vyriausybės žinios, 1938 m., Nr. 627). Vytauto Didžiojo karininkų kursų viršininkas, inspektorius, lektoriai ir kiti tarnautojai lieka Vytauto Didžiojo aukštosios karo mokyklos pareigūnais savo užimamose pareigose (LCVA, f. 384, ap. 1, b. 131, 1. 190).

Remiantis Vytauto Didžiojo Aukštosios karo mokyklos įstatymo 27 str. (Vyriausybès žinios, 1938 m., Nr. 627), krašto apsaugos ministras brg. gen. K. Musteikis ir kariuomenès vadas brg. gen. S. Raštikis 1938 m. gruodžio 19 d. paskelbe Vytauto Didžiojo aukštosios karo mokyklos statutą (LCVA, f. 384, ap. 1, b. 131, 1. 191-194).

1938 m. gruodžio 1-23 d. Vytauto Didžiojo aukštojoje karo mokykloje dèste 23 lektoriai: brg. generolai - S. Raštikis, V. Kiršinas, V. Žilys, S. Zaskevičius, V. Žadeika, I. Kraunaitis, B. Gertus, plk. V. Braziulevičius; Gen. štabo plk. 1tn. J. Rapšys, A. Špokevičius, J. Šepetys, V. Motieka; Gen. Štabo mjr. - V. Sutkus, N. Ferensas, V. Bulvičius, J. Ivašauskas, A. Šulcas-Šilius, prof. M. Romeris; docentai - P. Skardžius, D. Krivickas, V. Lazersonas; lektoriai - K. Dineika, S. Šačkus (LCVA, f. 1451, ap. 1, b. 106, 1. 1, b. 109, 1. 2, 16).

1939 m. liepos 8 d. Aukštoji karo mokykla išleido Generalinio štabo skyriaus III laidą, kurią baigè 19 karininkų: 1) plk. ltn. P. Daukšys, 2) mjr. P. Ver- 
telis, 3) kpt. J. Bulika, 4) kpt. V. Milius, 5) kpt. E. Krištaponis (Krikštaponis), 6) kpt. J. Valiulis, 7) kpt. L. Urnėžius, 8) kpt. A. Verksnys, 9) kpt. E. Bliudnikas, 10) kpt. A. Vaitkūnas, 11) kpt. S. Nacickas, 12) kpt. A. Karalius, 13) kpt. J. Puknys, 14) kpt. K. Adomonis, 15) kpt. H. Kazakaitis, 16) kpt. K. Antanavičius, 17) ltn. J. Kilius, 18) ltn. A. Leveckis, 19) ltn. J. Janulaitis (Mūsų žinynas, 1939, t. 37, Nr. 8 (174), p. 131, Kardas; 1939, Nr. 15 (317), p. 373).

Išleistuvių iškilmès prasidejo liepos $18 \mathrm{~d} .8 \mathrm{val} .50 \mathrm{~min}$. Karo muziejaus sodelyje, kur prie paminklo žuvusiesiems susirinko lektoriai ir klausytojai. 9.00 val. ị sodeli atvyko Vytauto Didžiojo aukštosios karo mokyklos viršininkas brg. gen. V. Karvelis ir su buvusiujų klausytojų vyresniuoju Gen. štabo plk. ltn. P. Daukšiu, orkestrui grojant gedulingą maršą, padejo vainiką ant Nežinomo kareivio kapo.

Pagerbę žuvusiujjų atminimą, mokyklos vadovybè, lektoriai ir išleidžiamieji susirinko ị Igulos bažnyčią pamaldoms, kuriose dalyvavo Vyriausybė, kariuomenès vadovybè, aukštieji karininkai ir svečiai. Mišias laikè ir pamokslą sakè vyriausias kariuomenès kapelionas kunigas kanauninkas A. Sabaliauskas.

Po pamaldų, 11 val. 15 min., Didžiojoje Lietuvos karininkų ramovès salëje prasidejjo iškilmingos išleistuvès. Garbès prezidiumą sudarè: Respublikos Prezidentas A. Smetona, Ministras Pirmininkas ats. brg. gen. J. Černius, Seimo pirmininkas inž. K. Šakenis, Ministro Pirmininko pavaduotojas K. Bizauskas, krašto apsaugos ministras brg. gen. K. Musteikis, švietimo ministras dr. L. Bistras, kariuomenés vadas bgr. gen. S. Raštikis ir mokyklos viršininkas brg. gen. V. Karvelis.

Iškilmingam išleistuvių aktui prasidejus, Vytauto Didžiojo karo mokyklos inspektorius Gen. štabo plk. V. Kiršinas perskaite įsakymą kariuomenei, kuriuo baigusiems Generalinio štabo skyrių karininkams suteiktos aukštojo karo mokslo baigimo teisès ir Generalinio štabo karininko vardas. Respublikos Prezidentas A. Smetona įteike diplomus, paspausdamas kiekvienam ranką.

Itteikus diplomus, kalbejo Respublikos Prezidentas A. Smetona, kariuomenès vadas brg. gen. S. Raštikis, mokyklos viršininkas brg. gen. V. Karvelis ir naujụju Generalinio štabo karininkų vardu buvęs klausytojas vyresnysis Gen. štabo plk. 1tn. P. Daukšys (Mūsų žinynas, 1939, t. 37, Nr. 8, p. 131).

Respublikos Prezidentas A. Smetona kalbèjo: „<...> Mes betgi žinome, kaip nelengva išauklèti vadai vienai ar kitai gyvenimo sričiai. Tatai pasiekiama palaipsniui. Ir mūsų buvo pirma ịkurta vidurinė karo mokykla, o tik paskum ir per ją priejjome ị aukštają karo mokyklą, Vytauto Didžiojo vardu pavadintą. Juk ir aukštasis karinis mokslas turi būti einamas savo krašte, nes jis yra daugiau praktinis, o ne teorinis, einamas iš savo krašto gyvenimo sąlygų. İ tokị metodą šiandien yra linkęs bet kuris mokymas.

Mūsų aukštoji karo mokykla kuo toliau, tuo bus stipresnè. Ji visą laiką bus reikalinga, nes vyresniesiems karininkams išèjus iš vadovybès, turès ateiti pasiruošę jaunieji. Tačiau vadų ruošim būti vadovaujamam arba ịsakomam. Jei taip, tai mokslas nesibaigia mokyklos metu, ypatingai turint akivaizdoje karinį mokslą, kur tiek daug esti technikos naujienų. Mokykla duoda metodą, išmoko karininką 
savarankiškai galvoti, savarankiškai darbą dirbti. Prie patyrimo, žinoma, pravartu ir knyga, ir teorijų sekimas <..>." (Kardas, 1939, Nr. 15 (317), p. 374).

Kariuomenès vado brg. gen. S. Raštikio kalba iškilmingojo posėdžio metu:

„Vytauto Didžiojo aukštosios karo mokyklos Generalinio štabo skyrius šiandien išleidžia jau trečiają diplomuotų karininkų laidą. Tai yra reikšmingas įvykis mūsų kariuomenès pažangoje, nes tokių karininkų mums dar reikia, ir jie mūsų kariuomenės štabuose ir pulkuose yra laukiami ir reikalingi.

Šios aukštosios karo mokyklos pirmosios ir antrosios laidų auklètiniai jiems dedamų vilčių neapvylè, nes praktiškame darbe ir gyvenime pasirode kaip gerai paruošti, darbštūs ir sąžiningi vadai ir darbininkai.

Būdamas tiesioginis ir artimiausias aukštosios karo mokyklos darbų ir mokymo prižiūrètojas, šiandien trečiosios laidos išleistuvių proga šiame iškilmingame posėdyje vyriausiojo ginkluotujų pajėgų vado, Vyriausybės ir garbingų svečiu akivaizdoje galiu viešai ir drąsiai pasakyti, kad ir šios trečiosios laidos auklètiniai yra visai gerai paruosti ir visiškai tinka sunkiam ir sudètingam Generalinio štabo karininko darbui. Tas darbas yra labai ịvairus: diplomuotas karininkas turi sugebèti dirbti operatyvinį, mobilizacinị, mokytojo, auklètojo, paskaitininko ir, pagaliau, pati sunkiausią ir atsakovingiausią vado darbą. Jau seniai praejjo tie laikai, kada Generalinio štabo karininkas turedavo būti tik geras teoretikas ir štabo darbo žinovas, kada, paskendęs štabo darbe, jis galėdavo pasidaryti net svetimas ir nesuprantamas svarbiausiajai ir didžiausiajai karininkų masei, tarnaujančiai rikiuotèje, pulkuose, ir kada toks atitrūkęs nuo praktikos teoretikas be jokio rikiuotès stažo pretenduodavo i aukštas vietas ir laipsnius ir tikrai avansuodavo net daug greičiau negu kiti jo kolegos. Jei didžiųjų valstybių kariuomenès, kurios dèl savo didelių resursų ir didelio diplomuotų karininkų skaičiaus, atrodo, galètų specializuoti karininkus net grynosios teorijos srityje, ir, vis delto, nuo to pradeda vis labiau ir labiau atsisakinèti, o jei ir turi gilius teoretikus, tai beveik visi jie yra su dideliu praktikos stažu; tai ką gi lieka besakyti apie mažųjų valstybių kariuomenes. Čia tokio liuksuso negalima sau leisti. Juk kokia būtų nauda iš tokio Generalinio štabo karininko, kuris teoretiškai galètu geriausiai vadovauti divizijoms, korpams ir armijoms, o praktiškai - susipainiotų lauke, gavęs vadovauti paprastą pėstininkų batalioną su viena artilerijos baterija ir kitais padedamaisiais ginklais.

Mums reikalingi, pirmiausia, vadai, gerai paruošti teoretiškai ir daug geriau praktiškai. Šiuo principu vadovaudamasi mūsų aukštoji karo mokykla stengiasi savo auklètiniams duoti minimumą teorijos ir maksimumą praktikos. Todèl ir pats dèstymas dažniausiai atliekamas praktiškai, ịvairių ịvairiausių uždavinių sprendimo forma žemėlapiuose ir laukuose. Be uždavinių sprendimo iš auklètinių dar reikalaujamas rikiuotės stažas ịvairiausių ginklų rūšių kariuomenès dalyse, pulkuose ir kiti praktiški darbai. Teorinès paskaitos mokykloje skaitomos tik tiek, kiek būtinai reikia ir be ko negalima apsieiti.

Šiam praktiškajam vadovavimo darbui šios dienos solenizantai yra gerai paruošti. 
Mieli kolegos! Mokyklos vadovybe ir lektoriai savo uždavinį atliko: jie davė jums tiek žinių ir praktikos, kiek turèjo ir galèjo duoti. Šiandien jūs oficiališkai apleidžiate mokyklos sienas ir, kiek pasiilsèję, eisite ị pulkus ir štabus, praktiškam ir savo kompetencijos ribose savarankiškam darbui dirbti. Iki šiol už jūsų darbus daugiau negu jūs buvo atsakingi lektoriai ir mokyklos vadovybè. Dabar už jūsų darbus visa atsakomybè teks jums patiems. Tai žinodami, mes stengiamès padèti ir jūsų ateičiai, duodami jums ne tik žinių, bet auklèjimo priemonèmis veikdami ir jūsų būdą. Stengiamès, kad jūs būtumète ryžtingi, drąsūs, stiprios valios, ištvermingi, griežti, drausmingi, savarankūs, aiškūs sprendimuose ir sumanymuose, konkretūs ir be tuščiažodžiavimo minčių dèstyme, kad priprastumète daug, gerai ir greit dirbti, kad nebijotumète nuovargio, purvo, dulkių, lietaus, šalčio ar karščio ir kitu nepatogumų, su kuriais mums, kariams, ypač karo metu teks dažnai susitikti. Aš čia nekalbu apie patriotizmą, pasišventimą, moralę ir kitas bendrąsias visiems kariams savybes, nes tai visiems mums turi būti visai suprantamas dalykas <...>." (Kardas, 1939, Nr. 15 (317), p. 375-377).

Vytauto Didžiojo aukštosios karo mokyklos viršininkas brg. gen. V. Karvelis detaliai apžvelgè trečiosios laidos klausytojų studijas: „Išleidžiant Vytauto Didžiojo aukštosios karo mokyklos Generalinio štabo skyriaus trečiąą laidą, turiu pranešti to skyriaus veiklą ir nudirbtus darbus. Visų pirma, tenka pasakyti, kad ši jau trečioji aukštosios mūsų karo mokyklos laida pradejjo savo darbą normaliu laiku - rudenị, būtent $1937 \mathrm{~m}$. rugsèjo $1 \mathrm{~d}$.

Pasiremiant dviejų išleistų laidų darbo patyrimu, šioje trečiojoje laidoje buvo padaryta kai kurių pakeitimų, papildymų ir patobulinimų. Darbo kiek padaugejo. Sumažėjo skiriamas atostogoms laikas. Padaugejo karo žaidimų ir lauko pratimų skaičius. Ivesti keli nauji dalykai. Pagausejjo ir sustiprejo lektorių kadras. Patobulejo mokymo metodas. Ir iš viso mokykla, pasiremdama išleistų dviejų laidų patyrimu, atsistojo ị normalias gyvenimo ir kūrybinio darbo vèžes, kurios ateityje turès būti dar daugiau plečiamos.

$<\ldots>$ Tenka pabrezžti, kad ir darbo sąlygos Vytauto Didžiojo aukštajai karo mokyklai gereja: jau kitai, ketvirtajai, laidai, kuri pradès darbą š. m. rugsejjo 1 d., praplečiamos patalpos ir padaugèja etatinių lektorių skaičius.

Baigdamas savo pranešimą, noriu priminti, kad baigti aukštajam karo mokslui reikia ilgesnio laiko ir itemptesnio darbo, negu baigti bendrajam civiliniam aukštajam mokslui, būtent: baigus aukštesniąją mokyklą, reikia išeiti trejų metu kursą karo mokykloje; po to ne mažiau kaip penkerius metus dirbti jau karininko darbą, igyti patyrimo, vèliau dvejus metus rengtis ir laikyti kas metai du stojamuosius egzaminus, kurių paskutinieji - konkursiniai. Konkursinius egzaminus išlaikius (ị mokyklą pakliūva tik apie 25-30 \% kandidatų), tenka vienerius metus stažuotis įvairiose ginklų rūšyse ir po to dvejus metus dirbti grynai akademinį darbą aukštojoje karo mokykloje. Pastarasis darbas reikalingas didelio jègų ịtempimo, metodingumo ir darbo drausmès <...>." (Kardas, 1939, Nr. 15 (317), p. 377-380).

1939 m. rugsèjo 1 d. Vytauto Didžioji aukštosios karo mokyklos Generalinio 
štabo skyriaus IV laida pradejjo mokslo metus, kilus Antrajam pasauliniam karui. Mokyklos lektoriai ir klausytojai susirinko ị auditoriją, kur atvyko kariuomenès vadas brg. gen. S. Raštikis ir mokyklos viršininkas brg. gen. V. Karvelis. Mokyklos viršininkas, pradėdamas mokslo metus, savo kalboje bendrais bruožais nurodè mokslo laiką, mokymo metodus, pratybų rūšis ir jų tikslą, pareikšdamas, kad „darbo itampa, sąlygos ir reikalavimai vyks laipsniškai. Darbas bus dirbamas sistemingai ir metodingai: iš pradžių taktinès aplinkybès bus lengvesnès, o vèliau jos sunkès ir darysis painesnès. Tai bus lyg užsigrūdinimas darbui. Igudus, be sistemos ir metodo bus reikalaujama dar ir greito darbo. Taip pat daug dèmesio bus kreipiama ir ị darbo drausmę, karinį stilių, savarankiškumą ir ị visa tai, kas darbą daro ramų, griežtą, aiškų, nuoseklų ir greitą.“ Toliau mokyklos viršininkas priminė, kad „buvusiųjų laidų patyrimu, dèl vieno kurio nors nepavykusio darbo nereikia nuleisti rankų ir nusiminti. Geras noras ir pastangos daug nulemia, todèl reikia dirbti, taisyti savąsias klaidas ir tobulèti. Darbui reikia atiduoti visą sielą ir pastangas, nes kaip tik tuo turi pasižymèti Generalinio štabo karininkas. Tačiau dirbant nereikia perdaug „persistengti“, nes žmogui reikalingas ir poilsis. Todèl laiką reikia taip tvarkyti, kad kiekvienas visada jaustųsi fiziniai ir dvasiniai atsparus ir pajègus darbui.“

Kariuomenès vadas brg. gen. S. Raštikis pažymėjo, kad „Aukštosios karo mokyklos Generalinio štabo skyriaus IV-oji laida šiandien pradeda darbą ne visai normališku laiku. Taip vadinamas baltasis arba nervų karas, o paskiausiomis dienomis ir gryni grupių kariniai pasiruošimai daug kur yra pasiekę aukščiausią įtempimą ir labai rimtai yra pastatytas klausimas - taika ar karas.

Tokiu momentu visiškai pasišvęsti rimtam studijų darbui yra gan sunku, nes pašaliniai reikalai ir rūpesčiai kreipia studijuojančiụjų dèmesị $i$ šalị ir trukdo sukaupti visas savo jėgas ir energiją vien tik studijų darbui. Tačiau šios aplinkybės kaip tik verčia kiekvieną iš mūsų pareikšti savo valios stiprumą, kad, neatsižvelgdami ị pašalinius trukdymus, sugebètume būti savo vietoje, dirbti mums pavestą darbą, nesiblaškyti ir išlaikyti šaltus nervus. Kiekvienoje mažiau ar daugiau atsakingoje vietoje esąs pareigūnas, o ypatingai karys, dabar daugiau negu kitu laiku turi būti karštas patriotas ir šventai pasiryžęs jam pavestas pareigas kaip galima geriau atlikti. Tik visų mūsų tautiečių tokio bendro darbo visuma gali padèti mūsų valstybei saugiau išsilaikyti išsisiūbavusioje karinių neramumų jūroje.

Aš sveikinu ketvirtają Generalinio štabo skyriaus laidą ir linkiu mokyklos viršininkui, lektoriams ir klausytojams geriausio pasisekimo šiandien prasidedančiame Tamstų darbe. Visų mūsų bendras ir nuoširdžiausias pageidavimas, kad kitur kylantieji pavojai mus neliestų ir netrukdytų mūsų darbui, kurio mes turime labai daug. Mes to darbo nenutrauksime iki paskiausio momento. O jei išbujoję ịvykiai sutrukdytų mums tą darbą dirbti, tai griebsimès kito darbo, kurio iš mūsų pareikalaus Tèvynès saugumas.

Dirbkite, kolegos, ramiai, nesiblaškydami, nesikarščiuodami, labai atidžiai ir sąžiningai semkitès šioje mokykloje jums skelbiamas ir duodamas žinias, visada atsimindami, kad kuo didesni būtų pavojai, tuo reikalingesnès bus jums tos žinios, 
ir kuo daugiau jų turèsite, tuo naudingiau bus jums patiems, visai kariuomenei, o tuo pačiu ir visam mūsų kraštui < ..>." (Kardas, 1939, Nr. 18 (320), p. 447-448).

Paskelbus dalinę mobilizaciją, rugsèjo $17 \mathrm{~d}$. Generalinio šabo ketvirtos laidos 23 klausytojai buvo komandiruoti ị savo dalis, o vyr. 1tn. Žagarnišas (Žagarinš - klausytojas iš Latvijos) buvo komandiruotas mokymo reikalais atlikti taktines pratybas lauke. Valstybès gynybos tarybos nutarimu, nuo $1939 \mathrm{~m}$. rugsejjo $25 \mathrm{~d}$. palaipsniui pradèta vykdyti kariuomenès demobilizacija, todèl 23 Generalinio štabo skyriaus klausytojai, o taip pat ir vyr. 1tn. Žagarnišas, 1939 m. lapkričio 22 d. atvyko i mokyklą tęsti studijas (LCVA, f. 858, ap. 1, b. 100, 3, 19; f. 1451, ap. 1, b. 109, 1. 25-26).

1940 m. balandžio 1 d. Vytauto Didžiojo aukštojoje karo mokykloje dèstė 6 kadro karininkai: brg. gen. V. Karvelis (mokyklos viršininkas), Gen. štabo plk. V. Kiršinas (mokyklos inspektorius), Gen. štabo plk. K. Sprangauskas (etatinis lektorius), Gen. štabo plk. ltn. A. Špokevičius (etatinis lektorius), Gen. štabo plk. 1tn. J. Šepetys (etatinis lektorius), kpt. S. Jurevičius (mokyklos raštvedys), laisvos dvi etatinių lektorių vietos, civilis tarnautojas (mokyklos raštvedys) P. Pilka. Todèl visiškai pasišvęsti rimtoms studijoms buvo gana sunku, nes karas blaškè studijuojančių karininkų dėmesị ir trukdè susikaupti mokslui.

Ketvirtoji laida buvo gausiausia, kurioje $1940 \mathrm{~m}$. balandžio $1 \mathrm{~d}$. mokèsi 25 karininkai: majoras A. Raugalė; kapitonai - A. Švažas, B. Gintautas, B. Bitinaitis, A. Tindžiulis, V. Ruseckas, P. Gužaitis, V. Vilkutaitis, J. J. Šukys, J. Kubiliūnas; leitenantai - M. Vinclovas, P. Petronis, V. Žibinskas, S. Aneliūnas, J. Namajūnas, V. Dulkè, V. Bagdonas, J. Gaižutis, P. Bandzinas, J. Zemeckis, J. Sadzevičius, J. Grajauskas, R. Alonderis, M. Vasiliauskas, V. Garbenis. Iš viso: 17 pėstininkų, 2 artilerijos, 4 kavalerijos, po vieną aviacijos ir inžinerijos specialybių ir klausytojas iš Latvijos kariuomenès vyr. 1tn. Žagarnišas (LCVA, f. 930, ap. 7, b. 7923, 1. 12).

1940 m. birželio 7 d. brg. gen. V. Karveli paskirus Kariuomenès štabo viršininko padejjëju, Vytauto Didžiojo aukštosios karo mokyklos viršininko pareigas pradeda eiti div. gen. S. Raštikis (LCVA, f. R-222, ap. 1, b. 7, 1. 132).

\section{Vytauto Didžiojo aukštosios karo mokyklos likvidavimas}

Sovietų Sajungai 1940 m. birželio 15 d. okupavus Lietuvą, prasideda mokyklos likvidavimas. Po dviejų dienų, t. y. birželio 17 d., Generalinio skyriaus ketvirtoji laida baigè pirmajj kursą ir 21 klausytojas kariuomenès vado div. gen. V. Vitkausko ịsakymu grąžintas ị savo dalinius. Mjr. A. Raugalè komandiruojamas ị Artilerijos inspekciją, o klausytojai kpt. V. Vilkutaitis, V. Šukys ir ltn. A. Vasiliauskas apsaugos reikalais komandiruojami ị geležinkelių komendantūrą, Latvijos kariuomenès vyr. 1tn. Žagarnišas, kuris mokèsi mokykloje ir baigè pirmą kursą, išvyko ị Latvijos ambasadą Kaune (LCVA, f. R-222, ap. 1, b. 9, 1. 7; f. 1451, ap. 1, b. 111, 1. 20-21).

Dar 1940 m. pradžioje pradèta rinkti Aukštosios karo mokyklos Generalinio štabo skyriaus penktoji laida. Iš 110 karininkų, išlaikiusių pirmuosius konkursinius 
egzaminus ir tinkančius sveikatos atžvilgiu, laikinai einančio kariuomenès vado pareigas div. gen. V. Vitkausko vasario 10 d. įsakymu Nr. 677 karininkams rugsèjo-spalio mèn. leista laikyti antruosius konkursinius egzaminus (LCVA, f. R-222, ap. 1, b. 9, 1. 42-43).

Respublikos Prezidento 1940 m. birželio 30 d. aktu Nr. 866 panaikintas 1934 m. Respublikos Prezidento aktas Nr. 385, kuriuo Vytauto Didžiojo karininkų kursų Generalinio štabo skyriaus pirmoji laida pavadinta Respublikos Prezidento Antano Smetonos generalinio štabo kursų laida, iš mokyklos pavadinimo išbrauktas Vytauto Didžiojo vardas, o rugsėjo 30 d. mokykla visiškai uždaroma (LCVA, f. R-222, ap. 1, b. 7, 1. 168).

Likviduojant aukštają karo mokyklą, vyko didelė personalo kaita. Vienus karininkus iškeldavo kitur, kitus atsiųsdavo ị mokyklą. Pvz., 1940 m. birželio 25 d. Respublikos Prezidento aktu Nr. 832 mokyklos etatinis lektorius Gen. štabo plk. K. Sprangauskas atleidžiamas iš pareigų ir skiriamas Kariuomenès štabo viršininko padèjëju, birželio 27 d. (aktu Nr. 861) mokyklos inspektorius Gen. štabo plk. V. Kiršinas atleidžiamas iš pareigu ir skiriamas Ypatingojo skyriaus santykiams su SSSR kariuomene Lietuvoje viršininku, etatiniai lektoriai: Gen. štabo plk. ltn. A. Špokevičius (aktu Nr. 860) - antrojo pėstininkų DLK Algirdo pulko vadu, o Gen. št. plk. 1tn. J. Šepetys - Ryšiu bataliono vadu (LCVA, f. R-222, ap. 1, b. $1,1.83$, b. $4,1.104)$.

Respublikos Prezidento liepos 6 d. aktu Nr. 971 Kariuomenès štabo II-ojo skyriaus viršininkas Gen. štabo plk. K. Dulksnys atleidžiamas iš pareigų ir formaliai skiriamas Aukštosios karo mokyklos etatiniu lektoriumi su pulko vado teisèmis, tačiau liepos 12 d. suimamas, kalinamas, oficialiai liepos 29 d. aktu Nr. 1256 atleidžiamas iš pareigų ir iš tikrosios karo tarnybos, paleidžiamas ị atsargą, $1941 \mathrm{~m}$. sušaudytas. Karo mokyklos viršininkas brg. gen. J. Juodišius liepos 29 d. aktu Nr. 1257 atleidžiamas iš pareigu ir skiriamas Aukštosios karo mokyklos etatiniu lektoriumi su pulko vado teisèmis, $1941 \mathrm{~m}$. suimtas, $1950 \mathrm{~m}$. žuvo Abezès lageryje. Panašaus likimo susilauke daugelis mokyklos absolventų ir dėstytojų, kurie buvo ištremti i Sovietų Sajungą ar nužudyti (LCVA, f. R-222, ap. 1, b. 1, 1. 63, b. 7, 1. 208).

Tuometinis kariuomenès vadas gen. S. Raštikis atsiminimuose rašè: „Naujose sąlygose aukštoji karo mokykla, kurios viršininku tada man teko būti, negalëjo veikti. Mokslas buvo nutrauktas ir klausytojai grąžinti ị pulkus. Aš likau beveik be darbo.“(Raštikis S., 1990, p. 72-73). 


\section{Išvados}

1. $1918 \mathrm{~m}$. vasario $16 \mathrm{~d}$. atkūrus Lietuvos valstybę ir pradejus organizuoti jos kariuomenę, imta rūpintis jos mokymu ir kvalifikacijos kèlimu. Lietuvos kariuomenè buvo kuriama nepaprastai sudètingomis sąlygomis - ịveikiant sunkius Pirmojo pasaulinio karo bei kaizerinès okupacijos padarinius ir kovojant su gausiais vidaus ir išorès priešais. Tačiau ir tais sunkiaisiais laikais kariuomenès mokymas nebuvo visiškai apleistas ir, kiek to meto sąlygos leido, kariuomenès mokymu ir jos tobulinimu buvo rūpintasi.

2. Siekiant suvienodinti karinio ir bendrojo karininkų išsimokslinimo lygi, visų ginklų rūšių karininkų tobulinimas buvo centralizuotas, ịsteigus $1921 \mathrm{~m}$. balandžio 1 d. Aukštuosius karininkų kursus, kurie nustojo veikti apie 1930-1932 m.

3. 1922 m. issakyme kariuomenei (Nr. 242) paskelbtas Steigiamojo Seimo priimtas Aukštujų karininkų kursų statutas, kuriuo steigiami du skyriai - Bendrasis su vienerių metų mokymo kursu ir Generalinio štabo skyrius (isteigtas tik $1931 \mathrm{~m}$.) su 2,5 metų mokymo kursu.

4. Iki $1931 \mathrm{~m}$. Lietuvoje nebuvo aukštojo karo mokslo institucijos, todèl nuo $1921 \mathrm{~m}$. pasitobulinti arba ịgyti retesnių karinių specialybių atrinkti karininkai buvo siunčiami ị Prancūzijos, Vokietijos, Italijos, Belgijos, Anglijos, Austrijos, Čekoslovakijos karo akademijas, intendantų, karo technikos, jūrų, kavalerijos mokyklas studijuoti aeronautikos, karo inžinerijos, radiotechnikos, elektrotechnikos, medicinos, veterinarijos, chemijos, mechanikos, meteorologijos, fizinio lavinimo ir kitu mokslų.

5. Visi Lietuvos generalinio štabo karininkai buvo baigę Europos valstybių aukštąsias karo mokyklas. Tačiau studijos užsienio karo mokyklose kèlè nemažai problemų. Kiekvienoje šalyje karo mokslas buvo pritaikytas prie tos šalies specifinių sąlygų, skyrèsi kariuomenių organizacinė struktūra, ginkluotė ir aprūpinimas. Be to, toks mokslas užsienyje brangiai kainavo (kasmet vidutiniškai mokèsi iki 10 karininkų; mokslas kainavo nuo 200 iki 400 tūkst. litų).

6. Paruošus pakankamą kvalifikuotų, su aukštuoju kariniu išsilavinimu karininkų skaičių, 1931 m. sausio 22 d. buvo įkurtas Vytauto Didžiojo karininkų kursų Generalinio štabo skyrius, kurio programa prilygo kitų valstybių generalinių štabų akademijų programoms. Šios kaip aukštosios karo mokyklos tikslas - rengti Lietuvos kariuomenei kvalifikuotus karininkus, suteikti jiems ne tik specialių, bendrų žinių, bet ir specifinio karininio mąstymo. Tačiau, ir ịsteigus $1931 \mathrm{~m}$. savają aukštąją karo mokyklą - Generalinio štabo skyrių, - ryšiai su užsienio mokyklomis nebuvo nutraukti.

7. 1938 m. gruodžio 10 d. Respublikos Prezidentas Antanas Smetona paskelbė Seimo priimtą ịstatymą, pagal kurị Vytauto Didžiojo karininkų kursai pavadinami Vytauto Didžiojo aukštaja karo mokykla, kurios tikslas - 1) suteikti karininkams aukštojo karo mokslo žinių, 2) kurti ir tobulinti karo mokslą ir jo rezultatus taikyti krašto sąlygoms ir poreikiams. Konkurso tvarka buvo priimama 25-30 karinin- 
kų. Mokslo trukmè - 2,5 metų. Mokyklos viršininkai buvo plk. Stasys Dirmantas (1929-1933 m.), Petras Kubiliūnas (1933-1934 m.), brg. gen. Vladas Karvelis (1936-1940 m.) ir div. gen. Stasys Raštikis (1940 m.), kuris ypatingai ja rūpinosi, dejjo daug pastangų, kaip geriau ir greičiau tobulinti Lietuvos kariuomenę.

8. Ši aukštoji karo mokykla rengė karininkus, kurie galètų dirbti Generaliniame štabe bei vadovauti dideliems kariniams daliniams. Aukštoji karo mokykla ypatingai vertinga dèl to, kad joje igyjamos žinios galèjo būti taikomos specifinèmis mūsų krašto sąlygomis. Joje jau buvo pradètos kurti naujos Lietuvai tinkamos karinès doktrinos. Spèta parengti 3 Generalinio štabo karininkų (57 karininkai) ir 1 intendantų laidą (7 karininkai). Ketvirtoji laida mokslo metus pradejo $1939 \mathrm{~m}$.

9. Dar 1940 m. pradžioje pradèta rinkti Aukštosios karo mokyklos Generalinio štabo skyriaus penktoji laida, tačiau, prasidejus sovietinei okupacijai, Vytauto Didžiojo aukštoji karo mokykla buvo uždaryta, daug absolventų ir dėstytojų ištremta ị Sovietų Sajungą ar nužudyta.

10. Taigi, nepaisant nepaprastai sudètingų vidaus ir išorès sąlygų, nepriklausomoje Lietuvoje buvo sukurta tobula ir efektyviai funkcionuojanti Lietuvos kariuomenès karininkų rengimo ir jų kvalifikacijos kèlimo sistema. Ši sistema užtikrino visų lygių karininkų rengimą, formavo įvairiapusiškai išsilavinusį karininkų korpusą, kurị sunaikino sovietinė okupacija.

\section{Literatūra ir šaltiniai}

\section{Archyviniai dokumentai}

1. Aukštujų karininkų kursų statutas, įsakymas kariuomenei Nr. 242, Kaunas, $1922 \mathrm{~m}$. lapkričio 4 d., Lietuvos centrinis valstybinis archyvas (toliau - LCVA), f. 384 , ap. 1, b. $46,1.242-243$.

2. Aukštujų karininkų kursų viršininko Gen. štabo gen. L. Radaus-Zenkavičiaus raportas Vyriausiojo štabo viršininkui plk. T. Daukantui, Kaunas, 1927 m. balandžio 18 d., LCVA, f. 1451, ap. 1, b. 33, 1. 11, 13.

3. Generalinio štabo plk. K. Škirpos raportas krašto apsaugos ministrui plk. A. Merkiui 1927 m. balandžio 27 d., Kaunas, 1927 m. gegužès 3 d., LCVA, f. 929 , ap. 6, b. $94,1.110$.

4. Generalinio štabo kursų kandidatams stažui kariuomenès dalyse atlikti bendri nurodymai (slaptas). Priedas Nr. 1 prie Kariuomenès štabo slapto aplinkraščio 1936 m. Nr. 14., LCVA, f. 929, ap. 6, b. 182, 1. 34.

5. Isakymas kariuomenei Nr. 92, Kaunas, 1927 m. liepos 27 d., LCVA, f. 384 , ap. 1 , b. $79,1.133-135$.

6. İsakymai kariuomenei Nr. 51, Kaunas, 1931 m. rugsèjo 17 d., LCVA, f. 384 , ap. 1, b. 99, 1. 136 .

7. Isakymai kariuomenei Nr. 20, Kaunas, 1932 m. kovo 10 d., LCVA, f. 384, ap. 1, b. $103,1.39$. 
8. Isakymai kariuomenei Nr. 62, Kaunas, 1933 m. rugsëjo 6 d., LCVA, f. 384, ap. 1, b. 108, 1. 75 .

9. Issakymai kariuomenei Nr. 69, Kaunas, 1933 m. rugsèjo 21 d., LCVA, f. 384 , ap. 1 , b. $108,1.84$.

10. Issakymai kariuomenei Nr. 8, Kaunas, 1934 m. sausio 25 d., LCVA, f. 384, ap. 1, b. 111, 1. 9 .

11. İsakymai kariuomenei Nr. 38, Kaunas, 1934 m. gegužès 18 d., LCVA, f. 384 , ap. 1, b. $111,1.12$.

12. İsakymai kariuomenei Nr. 44, Kaunas, 1934 m. birželio 7 d., LCVA, f. 384 , ap. 1 , b. $111,1.79$.

13. Isakymai kariuomenei Nr. 67, Kaunas, 1934 m. liepos 24 d., LCVA, f. 384 , ap. 1, b. 111, 1. 111 .

14. İsakymai kariuomenei Nr. 75, Kaunas, 1934 m. rugpjūčio 10 d., LCVA, f. 384 , ap. 1, b. $111,1.120$.

15. Issakymai kariuomenei Nr. 74, Kaunas, 1936 m. lapkričio 23 d., LCVA, f. 384 , ap. 1, b. $123,1.121$.

16. Issakymai kariuomenei Nr. 2, Kaunas, 1937 m. sausio 12 d., LCVA, f. 384, ap. 1, b. $127,1.8$.

17. İsakymas kariuomenei Nr. 37, Kaunas, 1937 m. birželio 28 d., LCVA, f. 384 , ap. 1, b. 127, 1. 55.

18. Isakymas Vytauto Didžiojo karininkų kursams Nr. 13, Kaunas, 1938 m. lapkričio 5 d., LCVA, f. 1451, ap. 1, b. 106, 1. 6.

19. İsakymas kariuomenei Nr. 90, Kaunas, 1938 m. gruodžio 17 d., LCVA, f. 384 , ap. 1, b. 131, 1. 190.

20. Issakymas Vytauto Didžiojo aukštajai karo mokyklai Nr. 15, Kaunas, 1938 m. gruodžio 30 d., LCVA, f. 1451, ap. 1, b. 106, 1. 1.

21. Isakymas Vytauto Didžiojo aukštajai karo mokyklai Nr. 2, Kaunas, 1939 m. vasario 4 d., LCVA, f. 1451, ap. 1, b. 109, 1. 2.

22. İsakymas Vytauto Didžiojo aukštajai karo mokyklai Nr. 10, Kaunas, 1939 m. rugsejjo 4 d., LCVA, f. 1451, ap. 1, b. 109, 1. 16.

23. Issakymas Vytauto Didžiojo karo mokyklai Nr. 11, Kaunas, 1939 m. rugsèjo 20 d., LCVA, f. 1451, ap. 1, b. 109, 1. 20.

24. Issakymas kariuomenei Nr. 14, Kaunas, 1939 m. rugsèjo 14 d., LCVA, f. 858 , ap. 1 , b. $100,1.1$.

25. İsakymas kariuomenei Nr. 16, Kaunas, 1939 m. rugsèjo 18 d., LCVA, f. 858 , ap. 1, b. $100,1.2$.

26. İsakymas kariuomenei Nr. 17, Kaunas, 1939 m. rugsèjo 14 d., LCVA, f. 858 , ap. 1 , b. 100,3 .

27. İsakymas Vytauto Didžiojo aukštajai karo mokyklai Nr. 14, Kaunas, 1939 m. lapkričio 27 d., LCVA, f. 1451, ap. 1, b. 109, 1. 25-26.

28. Isakymas kariuomenei Nr. 55, Kaunas, 1940 m. birželio 7 d., LCVA, f. R-222, ap. 1, b. 7, 1. 132. 
29. Issakymas Vytauto Didžiojo aukštajai karo mokyklai Nr. 20, Kaunas, 1940 m. birželio 25 d., LCVA, f. 1451, ap. 1, b. 111, 1. 20-21.

30. Kariuomenès štabo aplinkraštis Nr. 8, Kaunas, 1936 m. liepos 16 d., LCVA, f. 929, ap. 6, b. 183, 1. 68.

31. Kariuomenès štabo aplinkraštis Nr. 14, Kaunas, 1936 m. lapkričio 7 d., LCVA, f. 929, ap. 6, b. 182, 1. 31.

32. Kariuomenès štabo aplinkraštis Nr. 7, Kaunas, 1935 m. vasario 15 d., (slaptai) LCVA, f. 929, ap. 6, b. 169, 1. 67.

33. Kariuomenès aplinkraštis Nr. 22, Kaunas, 1935 m. lapkričio 30 d., LCVA, f. 929 , ap. 6, b. 170, 1. 128.

34. Kariuomenès štabo aplinkraštis Nr. 8, Kaunas, 1936 m. liepos 16 d., LCVA, f. 929, ap. 6, b. 183, 1. 68.

35. Kariuomenès štabo aplinkraštis Nr. 14, Kaunas, 1936 m. lapkričio 7 d., LCVA, f. 929, ap. 6, b. 182, 1. 31.

36. Kariuomenès vado ịsakymas Nr. 6, Kaunas, $1940 \mathrm{~m}$. vasario $10 \mathrm{~d}$., LCVA, f. R-222, ap. 1, b. 9, 1. 42-43.

37. Kariuomenès vado įsakymas Nr. 26, Kaunas, 1940 m. birželio 21 d., LCVA, f. R-222, ap. 1, b. 9, 1. 7.

38. Lietuvos Respublika. Generalinio štabo valdyba. III-sis skyrius, $1931 \mathrm{~m}$. sausio 22 d. Aplinkraštis Nr. 46049, LCVA, F. 929, ap. 6, b. 126, 1. 11.

39. Lietuvos Respublika. Generalinio štabo valdyba. III-sis skyrius, $1931 \mathrm{~m}$. balandžio 25 d. Aplinkraštis Nr. 46340, LCVA, F. 929, ap. 6, b. 126, 1. 46.

40. Lietuvos Respublika. Generalinio štabo valdyba. III-sis skyrius, $1931 \mathrm{~m}$. gegužès 19 d. Aplinkraštis Nr. 46435, LCVA, F. 929, ap. 6, b. 126, 1. 59.

41. Lietuvos Respublika. Generalinio štabo valdyba. III-sis skyrius, $1931 \mathrm{~m}$. sausio 22 d. Aplinkraštis Nr. 46049, LCVA, F. 929, ap. 6, b. 126, 1. 11.

42. Lietuvos Respublika. K. A. M. II pèstininkų divizijos III skyrius, Nr. 7231 (slaptas-asmeniškas, labai skubus), Kaunas, Šančiai, 1939 m. rugsèjo 25 d., LCVA, f. 858 , ap. 1, b. $100,1,19$.

43. Vytauto Didžiojo karininkų kursų Generalinio štabo skyriaus 1933 metams sąmatos projektas, LCVA, f. 1451, ap. 1, b. 31, 1. 9.

44. Vytauto Didžiojo karininkų kursų Generalinio štabo skyriaus $1933 \mathrm{~m}$. pedagoginis krūvio planas, LCVA, f. 1451, ap. 1, b. 31, 1. 10; b.84, 1. 7.

45. Vyriausiojo štabo aplinkraštis Nr. 25, Kaunas, 1932 m. lapkričio 16 d., LCVA, f. 1451, ap. 1, b. 90, 1. 8.

46. Vyriausiojo štabo aplinkraštis Nr. 4, Kaunas, 1933 m. vasario 20 d. Generalinio štabo valdybos III skyrius, LCVA, f. 929, ap. 6, b. 145, 1. 18.

47. Vytauto Didžiojo aukštosios karo mokyklos statutas, ịsakymas kariuomenei Nr. 91, Kaunas, 1938 m. gruodžio 19 d., LCVA, f. 384, ap. 1, b. 131, 1. 191-194.

48. Vytauto Didžiojo aukštosios karo mokyklos viršininko brg. gen. V. Karvelio raštas Kariuomenès štabo III skyriaus viršininkui. Vardinis karininkų sąrašas 1940 m. balandžio 1 d., slaptai-asmeniškai, LCVA, f. 930, ap. 7, b. 7923, 1. 12. 


\section{Knygos ir straipsniai}

1. Al. A., Savosios aukštosios kariškos mokyklos įsteigimo proga, Kardas, 1932, Nr. 5 (37), p. 66.

2. Andrušaitis, A., Respublikos Prezidento A. Smetonos generalinio štabo kursų laida, Kardas, 1934, Nr. 11 (188), p. 215.

3. Bulvičius, V., Generalinio štabo kursai, Kardas, 1935, Nr. 10 (215), p. 222.

4. Būkite pavyzdingi karininkai ir geri vadai. Kariuomenès vado brg. gen. S. Raštikio kalba iškilmingo posèdžio metu, Kardas, 1939, Nr. 15 (317), p. $375-377$.

5. II-oji Gen. štabo karininkų laida pradejjo savo mokslą, Kardas, 1935, Nr. 6 (211), p. 120-122.

6. Išleista Vytauto Didžiojo karininkų kursų Generalinio štabo skyriaus II laida ir Intendantų skyriaus I laida, Mūsų žinynas, 1937, t. 33, Nr. 7 (148), p. 85-86.

7. Jankauskas, J., Konkursui ị Aukštają karo mokyklą pasibaigus, Kardas, 1938, Nr. 23 (301), p. 557.

8. Jodauga, J., Kariuomenès mokymas, Lietuva 1918-1938. Leidinys skirtas 20 metų Lietuvos nepriklausomybès sukakčiai paminèti, Kaunas: Kooperacijos bendrove „Spaudos fondas“, 1938, p. 77-100.

9. Kaip ruošiami Lietuvos karininkai. Krašto apsaugos ministro brg. gen. S. Raštikio pareiškimas Seime (1938 m. spalio 11 d.), Karys, 1938, Nr. 41 (1009), p. 1143-1144.

10. Karvelis, V., Trečiąị trimestrą pradedant (Iš Generalinio štabo kursų veiklos), Kardas, 1935, Nr. 24 (229), p. 549-551.

11. Kiršinas, V., Reikšminga diena, Kardas, 1934, Nr. 11 (188), p. 217.

12. Kiršinas, V., Kelios mintys iš Vytauto Didžiojo karininkų kursų veiklos, Kardas, 1937, Nr. 8 (262), p. 185.

13. Kiršinas, V., Antroji taktinè kelionè, Kardas, 1937, Nr. 13 (267), p. 307-308.

14. Krašto apsaugos ministerijos stipendiju ịstatymo pakeitimas, Vyriausybès žinios, 1931 m. gegužès 16 d., Nr. 357, eil. Nr. 2426, p. 6.

15. „Mes džiaugiamès, kad mūsų mokytų karininkų padaugèjo ir karo mokslas sustiprèjo“, Respublikos Prezidento Antano Smetonos kalba, pasakyta per Aukštujų karininkų kursų išleistuves birželio 28 d., Kardas, 1937, Nr. 13 (267), p. 301.

16. Naujuosius Gen. štabo karininkus išlydint. V. D. aukšt. karo mokyklos v-ko kalba, Kardas, 1939, Nr. 15 (317), p. 378-379.

17. Pilka, P., Mokslą pradedant, Kardas, 1939, Nr. 18 (320), p. 447-448.

18. Ramanauskas, K., Vytauto Didžiojo karininkų kursų Intendantų skyriaus I laidą išleidžiant, Kardas, 1937, Nr. 13 (267), p. 309-310.

19. Raštikis, S., Ivykiai ir žmonès. Iš mano užrašų, t. 3, (1972), Čikaga: Akademinès skautijos leidykla.

20. Raštikis, S., Kovose dèl Lietuvos. Kario atsiminimai, (1990), Vilnius: 
Lituanus, II dalis.

21. Respublikos Prezidento žodis. V. D. aukšt. karo mokyklos III laidos išleistuviu proga (atpasakotas), Kardas, 1939, Nr. 15 (317), p. 374.

22. Škirpa, K., Susirūpinkime savo aukštosios mokyklos reikalu, Kardas, 1927, Nr. 13-14 (73-74), p. 180-182.

23. Valstybės Prezidento kalba Karininkų ramovejje, pasakyta gegužès 18 d. (trumpai suglausta), Kardas, 1934, Nr. 11 (188), p. 203-204.

24. Vytauto Didžiojo karininkų kursų viršininko Gen. štabo plk. V. Karvelio pranešimas kursantų išleistuvėse, Kardas, 1937, Nr. 13 (267), p. 303-306.

25. Vytauto Didžiojo karininkų kursų klausytojų išleistuvès, Kardas, 1937, Nr. 13 (267), p. 311.

26. Tèvynès meilè, garbè ir pareiga turi būti kiekvieno karininko gyvenimo rodyklè. Kariuomenès vado Gen. štabo plk. S. Raštikio kalba, pasakyta Vytauto Didžiojo karininkų kursų klausytojų išleistuvėse, Kardas, 1937, Nr. 13 (267), p. 302.

27. Vytauto Didžiojo karininkų kursų klausytojų išleistuvès, Kardas, 1937, Nr. 13 (267), p. 311-312.

28. Vytauto Didžiojo karininkų kursų Generalinio štabo skyriaus išleistuvès, Karys, 1937, Nr. 27 (954), p. 744.

29. Vytauto Didžiojo karininkų kursų Generalinio štabo skyriaus III laidos mokslo pradžia, Kardas, 1937, Nr. 18 (272), p. 410.

30. Vytauto Didžiojo aukštosios karo mokyklos ịstatymas, Vyriausybès žinios, 1938 m. gruodžio 10 d., Nr. 627, eil. Nr. 4503, p. 557-558.

31. V. D. aukštosios karo mokyklos išleistuvès, Mūsų žinynas, 1939, t. 37, Nr. 8 (174), p. 131. 


\title{
VYTAUTAS THE GREAT HIGHER MILITARY \\ SCHOOL (1931-1940)
}

\author{
Assoc. Prof. Dr. Feliksas Žigaras
}

\section{Summary}

When on 16 February 1918 Lithuania restored its independence, the restoration process of the armed forces began as well. The Lithuanian Armed Forces were assembled in very difficult circumstances as they had to deal with the consequences of the World War I, German occupation and numerous internal and external enemies. Nevertheless, military training was conducted and developed further.

To standartise officer training, Senior Officer Training Course was launched on 1 April 1921; however, discontinued during the period of 1930-1932.

By the Order No. 242 of the Seimas in 1922, the Statute of the Senior Officer Training Course was passed providing for the general course (1 year) and staff officer training course ( 2.5 years) that was actually established only in 1931.

Until 1931, there was no senior officer training institution; therefore, since 1921 officers were sent to French, German, Italian, Belgian, UK, Austrian and Czechoslovakian military academies and intendant, technical, naval and cavalry schools to study aeronautics, military engineering, radiotechnics, electrotechnics, medicine, veterinary, chemistry, mechanics, physical training, etc.

All staff officers had foreign higher military education. However, foreign military studies were complicated as every country designed them to its needs and circumstances. Also, the education was expensive and only 10 officers could be given such grants (200-400 thousand Litas) every year.

When a sufficient number of officers having higher military education was reached, the Vytautas the Great Staff Officer Training Course was launched on 22 January 1931. Its program was equivalent to training programs at foreign military schools. The purpose of the course was to train qualified officers for the Lithuanian Armed Forces and develop various skills.

On 10 December 1938, President Antanas Smetona issued an order ratified by the Seimas to transform the Vytautas the Great Officer Training Course to higher military school. Its purpose was to train officers high-level military subjects and develop and use in practice military sciences. Only 25-30 officers at a time could attend the course. The training lasted for 2.5 years. The commandants of the military school were as follows: Colonel Stasys Dirmantas (1929-1933), Colonel Petras Kubiliūnas (1933-1934), Brigadier General Vladas Karvelis (1936-1940) and Division General Stasys Raštikis (1940). The latter devoted much time and 
effort to the development of the school.

The military school educated staff officers and commanders. Its contribution was extremely valuable to the country because the education was aimed at local needs. Unfortunately, the school was closed by the time military doctrines were developed. In total, 3 classes of 57 staff officers and 1 class of 7 intendants completed the course. The fourth class started training in 1939. At the beginning of 1940, when the fifth class was about to start training, the Soviet occupation put a halt to it. Many instructors and students were killed or deported.

Despite the difficulties, independent Lithuania had a well-functioning officer training system of all-level leadership education that was destroyed by the Soviet occupation.

\section{AUTORIAUS LYDRAŠTIS}

Autoriaus vardas, pavardè: Feliksas Žigaras

Mokslo laipsnis ir vardas: docentas, daktaras

Darbo vieta ir pareigos:

Autoriaus mokslinių interesų sritys: Lietuvos tarptautinis bendradarbiavimas; Lietuvos, Latvijos ir Estijos santykiai; pilietinio ugdymo raida, patirtis, Lietuvos kariuomenès problemos, jų sprendimo būdai; Lietuvos kariuomenès karininkų rengimas (1919-1940 m.); Lietuvos kariuomenès karininkų rengimas (1990-2017 m.)

Telefonas ir el. pašto adresas: + 37061284 775;

feliksas.zigaras@yahoo.com

\section{AUTHOR'S COVER LETTER}

Author's name and surname: Feliksas Žigaras

Academic degree and name: Associate Professor, Doctor

Workplace and position:

Author's research interests: international cooperation of Lithuania, relationship among Lithuania, Latvia and Estonia, civic education development, experience and problems of the Lithuanian Armed Forces and their solutions, Lithuanian officer training in the period of 1919-1940, Lithuanian officer training and training system development in the period of 1990-2017

Telephone and e-mail address: + 37061284 775;

feliksas.zigaras@yahoo.com 